\title{
Voleybol Hakemlerinin Ego ve Görev Yönelimleri Bakımından Öz Yeterliklerinin İncelenmesi
}

\author{
Examination of Self-Efficacy of Voleyball Referees in Terms of Ego and Task Orientations
}

$$
\text { Nazlı EKMEKÇí[1] Aylin ZEKİOĞLU[2] Nihal DAL }{ }^{[3]}
$$

Bu çalışmanın amacı voleybol hakemlerinin ego ve görev yönelimleri ile öz yeterlikleri arasındaki ilişkinin demografik özellikleri bakımından araştırılmasıdır. Araştırmanın çalışma grubu 2017-2018 sezonunda İzmir, Kayseri, Denizli, Aydın, Ankara, İstanbul ve Isparta illerinde faal olarak görev yapan 279 voleybol hakeminden oluşmaktadır. Veri toplama aracı olarak Sporda Ego ve Görev Yönelimi Ölçeği ve Hakem Öz Yeterlik Ölçeği ile Sosyo-Demografik Veri Formu kullanılmıştır. Verilerin değerlendirilmesinde Tek Yönlü Varyans Analizi ve bağımsız örneklem t-testi kullanılmıştır. Varyans analizlerinde gruplar arası farklılık için Tukey-B çoklu karşılaștırma testi uygulanmıştır. Fiziksel yeterlik, oyun bilgisi, karar verme, baskı, iletişim, HÖYÖ toplam puanı ve görev yönelimi alt boyutlarının birbirleri ile; ego yönelimininse sadece görev yönelimi alt boyutu arasında anlamlı bir ilișki bulunmuștur. Cinsiyet gruplarına göre fiziksel yeterlik ve karar verme, yaş ve deneyim gruplarının karar verme, klasman gruplarının karar verme ve ego yönelimi ve şehir gruplarının ego yönelimi alt boyutu toplam puan ortalamaları arasında istatistiksel olarak anlamlı bir fark bulunurken meslek gruplarının alt boyut toplam puan ortalamaları arasında anlamlı bir fark bulunamamıștır. Araştırmanın sonucunda voleybol hakemlerinin ego ve görev yönelimleri ile öz yeterlikleri arasında anlamlı bir ilişki olduğu görülmüş ve cinsiyet, yaş, deneyim, şehir ve klasman değişkenleri arasında farklılıklar bulunmuştur.

Anahtar Kelimeler: ego yönelimi, görev yönelimi, öz yeterlik, hakem

The aim of this study is to investigation of the relationship between "ego and task orientation" and "self-efficacy" of volleyball referees in terms of demographic features. The study group consists of 279 volleyball referees working actively in Izmir, Kayseri, Denizli, Aydin, Ankara, Istanbul and Isparta during the 2017-2018 season. "Ego and Task Orientation Scale in Sports", "Referee SelfEfficacy Scale" and "Socio-Demographic Data Form" were used as data collection tools. One-way Analysis of Variance and comparison results with t-test for unconnected groups were included in the evaluation of the data. Tukey-B multiple comparison test was used for the difference between groups in variance analysis. A significant correlation was found among physical competence, game knowledge, decision making, pressure, communication, total score and task orientation sub-dimensions; task orientation and sub-dimension of ego orientation only had a correlation between them. Physical competence and decision-making sub-dimension according to gender groups, age and experience groups, ego orientation sub-dimension of the classification groups had a statistically significant difference in the total scores of the ego orientation sub-dimension of the city groups, while there was no significant difference in the total scores of the sub-dimension of the occupational groups. As a result, it was seen that there were differences among variables of gender, age, experience, city and classification for volleyball referees, but there was a significant relationship between "ego and task orientation" and "self-efficacy".

Keywords: ego orientation, task orientation, self-efficacy, referee 


\section{GíRiş}

$\mathrm{S}$ por sosyal bir olgu olarak, her yaş kademesi ve meslekten katılım ve izleyici bulur (Öztürk, 1997). Bu alanda yapılan araştırmalar ve var olan teknolojik gelişmeler sonucunda sporun multidisipliner bir branş olarak farkındalık yaratmaya başladığını göz önüne sermiştir. Sporda başarı güdülenmesi içerisinde sportif davranışın yapısını bu disiplinden biri olarak spor psikolojisi incelemektedir (Kaygusuz vd., 2016). Nicholls'un öne sürmüş olduğu hedef yönelimi kuramı, (Duda, 1989) tarafından spor alanında uygulanmış ve hedef yönelimi üzerine yapılan araştırmalar bizlere iki bağımsız başarı fikrinin olduğunu göstermiștir. Bunlar görev yönelimli hedefler ve ego yönelimli hedeflerdir (Duda ve Nicholls, 1992). Bireylerin yetenek düzeyi ile bu iki hedef yönelimi birbiriyle ilişkilidir (Toros, 2000). Hedef yönelimlerinden biri olan görev yönelimli hedeflere sahip olan bireyin, beceri gelişimi, yeni beceri öğrenme, görevde ustalığı gösterme ve sıkı çalışma üzerinde odaklandığı belirtilmektedir (Toros, 2001). Bir diğer hedef yönelimi olan ego yönelimli hedeflerde ise, bireyin etrafına kendini kanıtlamaya çabası içerisinde olduğu belirtilmektedir. Ego yönelimli hedeflerde; yarışma içerisinde daha az çaba ile rakiplerini alt etme birey için bireysel başarının kaynağı olarak görülmektedir (Toros, 2002). Ayrıca "en iyi” olmak başkalarına göre üstün olmak anlamına geldiği için ego yönelimli hedeflerde "kazanmak” oldukça önemlidir (Bray vd., 2004).

Fiziksel gelişim ile birlikte ruhsal ve sosyal sağlığın korunmasında etkili olan voleybol gibi branşların kurallar içerisinde sistemli bir şekilde yürütülebilmesi için hakemler gibi bu müsabakaları yönetenlere ihtiyaç duyulmaktadır. Hakemler federasyonların belirledikleri kurallar ve yetkilerle üzerlerine yüklenen sorumluluklar içerisinde müsabakaları yönetmek gibi önemli bir görevi yerine getirmeye çalışmaktadırlar (Karataş vd., 2013). Bu bağlamda hakem ve davranışları başarıyı etkileyen en önemli faktörlerden biridir (Pepe vd., 1999). Sporcu ve hakemlerin farklı değer ve hedefleri vardır. Bu farklılık da bizlere hakemlerin sporculardan farklı görev yönelimleri olduğunu göstermektedir. Hakemlerin içinde bulunduğu ortamı etkileyen faktörleri de inceleyerek bu alanda katkı sağlamak önemlidir.

Spor ve egzersiz psikologları göre birçok motivasyon tarzları vardır (Weinberg ve Gould, 1995). Bireyin spor faaliyetleri için motivasyon sağlamasının temelinde her bireyin farklı amaçlarla spora katıldıkları anlaşılmıştır (Walling ve Duda, 1995). Buna uygun olarak (Duda, 1989), (Duda ve White, 1992) sporda hedeflere ulaşma ve başarı güdülenmesinde Nicholls'un gelişimsel temelli algllanan yetenek kuramından etkilenerek iki temel stil ayırt etmişlerdir. Bunlardan birincisi görev ile ilişkili hedef yönelimidir. Görev yönelimini benimseyen sporcular beceri gelişimini, öğrenmeyi, görevde ustalaşmayı, takım uyumunu ve işbirliğini önde tutarken (Duda vd., 1995), görev ile ilişkili hedef yöneliminin doyum, sporla içsel yönden ilgilenme, keyif alma ile olumlu yönde ilişkili olduğunu bulmuşlardır. İkincisi ise ego yönelimidir. Ego yönelimli hedeflere sahip olan bireyler üstünlük kurmaya, rakiplerini yenmeye ve yapılan çalışmanın sonucuna odaklaşırlar. Çalışmalar, ego yönelimli hedeflere sahip olan bireylerde direnç azlığı, yüksek kaygı düzeyine, 
sportif çalışmalardan daha az keyif alma ve doyuma yol açtı̆̆ını göstermektedir (Boyd, 1990; Duda, 1992; Duda ve Chi, 1989).

Sporda hedef yönelimi araştırmaları son zamanlarda oldukça artmış, yurtiçinde ve yurtdışında bu alanda yapılan çalışmalar literatürü zenginleştirmeye başlamıştır. Türkiye ve yurtdışında yapılan başlıca hedef yönelimi çalışmalarını inceleyebiliriz.

Biçimlendirmeye yönelik değerlendirme sürecinin performansa dayalı tekniklerle yürütülerek bireylerin baskın olan hedef yönelimleri üzerindeki etkisinin incelenmiş olduğu araştırma sonucunda performansa dayalı tekniklerle yürütülen biçimlendirmeye yönelik değerlendirme sürecinin öğrencilerin baskın olan hedef yönelimi üzerinde kısmen etkili olduğu sonucuna ulaşılmıştır. Bu sonuçlara göre deneysel işlem süreci bitiminde bireylerin öğrenme-yaklaşma yönelimine sahip olurken performans-yaklaşma yönelimine sahip olma düzeylerinde düşüş olduğu görülmüştür. Bireylerin öğrenme-kaçınma ve performans kaçınma yönelimine sahip olma düzeylerinde ise anlamlı bir farklılık olmadığı belirtilmiştir (Buldur ve Doğan, 2017).

Serbest ve grekoromen stil güreşçilerinin yaşam doyumu ile hedef yönelimler arasındaki ilişki incelendiğinde grekoromen stil ve serbest stil tüm güreşçilerin yaşam doyumları ile hedef yönelimleri arasında aylık gelir, başarı düzeyi, yaş ve deneyim değișkenleri arasında farklılıklar olduğu görülmüștür. Güreşçilerin yaşam doyumu ile hedef yönelim düzeyleri arasında anlamlı ilişki bulunmuştur (Toy, 2015).

Lise ve üniversite düzeyinde spor yapan bireylerin, daha genç ve rekreasyonel amaçla spor yapan bireylerle karşılaştırılması sonucunda ego ile ilişkili hedef yönelimlerinin daha yüksek olduğu ayrıca rekreasyon amaçlı katılımcı olan liseli erkek sporcuların ise daha düşük görev ile ilişkili hedef yönelimi gösterdikleri görülmüştür. Cinsiyet farkları incelendiğinde ise erkek sporcuların ego yönelimlerinin daha yüksek olduğu bulunurken, kadın sporcuların ego yönelimlerinin daha düşük olduğu saptanmıştır (White ve Duda, 1994). Bu Araştırma sonuçları ile ilgili olarak ego ile ilişkili hedef yöneliminin kadın sporcularda düşük olmasının nedeni toplumsal normların, kadının kimliğini etkileyebileceği ve dolayısıyla kadının yetişme şeklindeki toplumsal etkinin ego ile ilişkili hedef yönelimini baskıladığı düşünülmektedir.

Yapılan bu çalışmada görev ile ilişkili hedef yönelimi yüksek oyuncular, takım ortamını ustalık iklimi olarak algıladığı ve buna bağlı olarak bu tür sporcuların aktivitelerden daha çok doyum aldıkları bulunmuştur (Duda, ve Nicholls, 1992).

Motive olma, özgüven ve başarı arasında olumlu yönde bir ilişki olması nedeniyle (Jacobsen vd., 2002), bu becerilerin yüksek düzeyde olması başarıyı artırırken, düşük düzeyde olması ise başarıyı azaltmaktadır. Yüksek düzeyli öğrenmenin meydana gelebilmesi için bireylerin kendilerine güven duymaları gerekmektedir ve böylece öğrenme sürecinde kendilerini daha iyi hissederler (Ornstein ve Lasley, 2000).

\section{Çalışmanın Önemi ve Amacı}


Araştırmanın temel amacı elde edilen sonuçlar çerçevesinde sporun bir parçası olan hakemlerin öz yeterlik düzeylerinin hedef yönelimler açısından incelenerek çıkan sonuçların birbirleri ile nasıl ilişkisi olduğu belirlenerek hakemlere katkı sağlaması olarak belirlenmiștir.

1. Voleybol hakemlerinin sporda ego ve görev yönelimleri ile öz yeterlikleri arasında ilişki var mıdır?

2. Voleybol hakemlerinin hedef yönelimleri düzeyi hangi seviyededir?

3. Voleybol hakemlerinin öz yeterlik düzeyleri hangi seviyededir?

4. Voleybol hakemlerinin öz yeterliğin boyutları olan fiziksel yeterlik, oyun bilgisi, karar verme, baskı, iletişim ve hedef yönelimlerin alt boyutları olan ego ve görev yönelimi düzeyleri arasında anlamlı bir ilişki var mıdır?

5. Voleybol hakemlerinin cinsiyetleri, yaşları, meslek, deneyim yılları ve klasmanları arasında anlamlı bir ilişki var mıdır?

\section{YÖNTEM}

\section{Araştırma Modeli}

Bu kesitsel araştırmada, seçkisiz örneklem yöntemi kullanılmıştır. Seçkisiz örneklem yöntemlerinin temel özelliği, örneklemin evreni temsil etme gücünün son derece yüksek olmasıdır. Bununda ön koşulu, örnekleme birimlerinin örneklem seçilme olasılıklarının eşit ve birbirinden bağımsız olması olarak açıklanan seçkisizlik kuralına uyulmasıdır. Bu yöntemler ile evrene geçerli genellemelerin yapılabileceği temsil yüksek potansiyele sahip örneklemlerin oluşturulması hedeflenmektedir (Büyüköztürk vd., 2014).

\section{Çalışma Grubu}

Bu araștırmanın evreni 2017-2018 Sezonunda TVF bağlı ve aktif olarak hakemlik yapmaya devam eden voleybol hakemlerinden oluşmaktadır. Araştırmanın örneklem grubu İzmir (\%24.4), Kayseri (\%10.9) , Denizli (\%8) , Aydın (\%10.5), Ankara (\%18.2) , İstanbul(\%19.6) ve Isparta(\%8.4) illerinde sezona aktif olarak devam eden ve gönüllü olarak çalışmaya katılmış 129 kadın (\%47.1) 145 erkek (\%52.9) olmak üzere toplam 274 voleybol hakeminden oluşmaktadır.

Örnekleme dahil edilen katılımcllara ait demografik bilgiler Tablo 1'de sunulmuştur. 
Voleybol Hakemlerinin Ego ve Görev Yönelimleri Bakımından Öz Yeterliklerinin İncelenmesi

\section{Tablo 1}

Sosyo demografik değişkenlerin dağılımı

\section{Değişken}

Gruplar

Kişi Sayısı (n)

Yüzde (\%)

\begin{tabular}{|c|c|c|}
\hline 18-25 Yaş & 102 & 38.1 \\
\hline 26-33 Yaş & 76 & 28.4 \\
\hline 34-41 Yaş & 45 & 16.8 \\
\hline 42-49 Yaș & 25 & 9.3 \\
\hline 50 yaş ve üzeri & 20 & 7.5 \\
\hline Toplam & 268 & 100.0 \\
\hline Kadın & 129 & \multirow{3}{*}{$\begin{array}{c}47.1 \\
52.9 \\
100.0\end{array}$} \\
\hline Erkek & 145 & \\
\hline Toplam & 274 & \\
\hline Özel Sektör & 18 & 15.4 \\
\hline Kamu Çalışanları & 50 & 42.7 \\
\hline Diğerleri & 49 & \multirow{2}{*}{$\begin{array}{c}41.9 \\
100.0\end{array}$} \\
\hline Toplam & 117 & \\
\hline $1-5 \mathrm{yll}$ & 137 & 51.5 \\
\hline 6-10 yll & 48 & 18.0 \\
\hline $11-15$ yll & 35 & 13.2 \\
\hline $16-20$ yll & 25 & 9.4 \\
\hline $21-25$ yll & 11 & 4.1 \\
\hline 26 yıl ve üzeri & 10 & \multirow{2}{*}{$\begin{array}{c}3.8 \\
100.0\end{array}$} \\
\hline Toplam & 266 & \\
\hline Aday & 73 & 26.8 \\
\hline Il & 90 & 33.1 \\
\hline Ulusal & 104 & 38.2 \\
\hline Uluslararası & 5 & \multirow{2}{*}{$\begin{array}{c}1.8 \\
100.0\end{array}$} \\
\hline Toplam & 272 & \\
\hline İzmir & 67 & 24.4 \\
\hline Kayseri & 30 & 10.9 \\
\hline Denizli & 22 & 8.0 \\
\hline Aydin & 29 & 10.5 \\
\hline Ankara & 50 & 18.2 \\
\hline İstanbul & 54 & 19.6 \\
\hline Isparta & 23 & 8.4 \\
\hline Toplam & 275 & 100.0 \\
\hline
\end{tabular}

Meslek

Klasman

Deneyim

Şehir

Aydın

29

8.0

Ankara

18.2

19.6

100.0

Veri Toplama Araçları 
$\mathrm{Bu}$ araştırmada hakemlerin sporda ego ve görev yönelimlerini ölçen "Sporda Görev ve Ego Yönelimi Ölçeği”, ile hakemlerin öz yeterlik düzeylerini ölçen "Hakem Öz Yeterlik Ölçeği” kullanılmıştır. Ayrıca araştırma kapsamında demografik bilgileri elde etmek için de "Demografik Bilgi Formu” kullanılmıștır.

Sporda Ego ve Görev Yönelimi Ölçeği (SEGYÖ). Duda Joan L. (1989, 1992), Duda ve Nicholls (1992) tarafından geliştirilmiş ve daha sonra Toros Turhan (2004) tarafından Türk sporcular için güvenirlik ve geçerliğinin çalışması yapılan "Sporda Görev ve Ego Yönelimi Ölçeği -SGEYÖ-"nin, spor hakemleri için adaptasyon çalışması Doğan vd., (2017) tarafından yapılmıştır. SGEYÖ-13'deki maddeler altı maddesi ego yönelimli hedefler, yedi maddesi görev yönelimli hedefler olmak üzere iki faktöre dağıtılmaktadır. SEGYÖ-'de toplam 13 adet madde bulunmaktadır ve bu maddeler altı maddesi ego yönelimli hedefler, yedi maddesi görev yönelimli hedefler olmak üzere iki faktöre dağıtılmaktadır. Alt boyutlar; Ego yönelimli $(1,3,4,6,9,11)$, Görev yönelimli $(2,5,7,8,10,12,13)$ başlıkları halinde sıralanır. Elde edilen bulgulara göre yapılan faktör analizi sonucunda maddeler orijinal ölçekte olduğu gibi iki faktör altında toplanmakta ve boyutlar ise toplam varyansın \%53.19'ini açıklamaktadır. Ölçeğin alt boyutlarına ait madde-test korelasyonları incelendiğinde, maddelerin birbiri ve toplam puan ile anlamlı şekilde ilişkili olduğu görülmüştür. Aynı zamanda ölçeğin yüksek güvenirlik katsayılarına sahip olduğu belirlenmiştir (Cronbach Alpha güvenirlik katsayısı: Görev yönelimli hedefler .82, ego yönelimli hedefler .83 ve genel .83). Bulgular, sporda görev ve ego yönelimi ölçeğinin hakemler için kullanılabileceğini göstermiştir (Doğan vd., 2017).

Hakem Öz Yeterlik Ölçeği (HöYÖ). Orijinal formu Myers vd., (2012) geliştirdikleri Hakem Öz Yeterlik Ölçeği'nin (HÖYÖ) Türkçe versiyonunu fiziksel yeterlik faktörü ekleyerek Karaçam ve Pulur (2017) geliştirmiştir. Ölçek 5'li likert, fiziksel yeterlik boyutununda eklenmesiyle 5 alt boyuttan ve 18 maddeden oluşmaktadır.

Alt boyutlar; Fiziksel yeterlik $(1,2,3,4,5)$, Oyun bilgisi $(6,7,8)$, Karar verme $(9,10,11)$, Baskı $(12,13,14)$, Iletişim $(15,16,17,18)$, başlıkları halinde sıralanır. Bileşenlerin analizi sonucu, öz değerleri 1'den büyük beş bileşenli bir yapı ortaya çıkmıştır. Ölçek bileşenleri için alfa iç tutarlık katsayılarının fiziksel yeterlik faktöründe 0,88 , oyun bilgisi faktöründe 0,71 , karar verme faktöründe 0,85 , baskı faktörü 0,88 , iletişim faktöründe 0,81 ve ölçeğin tümü için 0,90 olduğu görülmüştür. Sonuçlar fiziksel yeterlik faktörü eklenen beş faktörlü ölçeğin Türkçe versiyonunun geçerli ve güvenilir olduğunu göstermektedir. (Karaçam, Aydın ve Pulur, Atilla 2017).

Sosyo-Demografik Bilgi Formu. Araştırmacı tarafından geliştirilen bu form 6 sorudan oluşmaktadır. Bu form ile katılımcıların yaş, cinsiyet, meslek, deneyim, klasman ve şehir ile ilgili bilgiler toplanmaya çalışılmıştır. Katılımcıların kimlik ve özel bilgilerine yönelik herhangi bir soru sorulmamıştır.

\section{Verilerin Toplanması}

Bu çalışma için Manisa Celal Bayar Üniversitesi Sağlık Bilimleri Enstitüsü Etik Kurulu'ndan gerekli onay alınmıştır (17.01.2018/ 20.478.486). Ayrıca verilerin toplanması için çalışma grubunun bağlı bulunduğu Türkiye Voleybol Federasyonu (TVF)'ndan kurumsal izin alınmıştır. Araştırmacı tarafından hazırlanan ve 
ölçekleri içeren form belirtilen illerdeki hakem gruplarına posta yoluyla iletilmiş ve formlar hakemler tarafindan doldurulup tekrar posta yoluyla geri gönderilmiştir.

\section{Verilerin Analizi}

$\mathrm{Bu}$ çalışmanın verileri SPSS programı 21.00 versiyonu ile analizi edilmiştir. Veriler, önce bağımsız değişkenlerin sayı yüzde dağılımları, bağımlı değişkenlerin yani sporda ego ve görev yönelimi ölçeği alt boyutları ve hakemlerde öz yeterlik ölçeği alt boyutları toplam puanlarının betimleyici istatistikleri, ölçeklerin güvenirlik ve madde analizi, iki ölçek ve alt boyutların arasında Pearson Çarpım Moment Kolerasyon Katsayısı analizi, sosyo-demografik bağımsız değişkenlerin kategorilerinin birbirleriyle, sporda ego ve görev yönelimi ölçeği alt boyutları ve hakem öz yeterlik ölçeği alt boyutları toplam puanları açısından tek yönlü varyans analizi ve bağımsız örneklem için t-testi ile karşılaştırma sonuçlarına yer verilmiştir. Varyans analizlerinde gruplar arası farklılık elde edildiği koşulda hangi grubun hangi gruptan farklı olduğunu saptamak için de Tukey-B çoklu karşılaştırma testi uygulanmıştır.

\section{BULGULAR ve YORUM}

\section{Tablo 2}

Cinsiyet grupları açısından hakem Öz Yeterlik Ölçeği fiziksel yeterlik, oyun bilgisi, karar verme, baskl, iletişim alt boyutları ve hakem Öz Yeterlik Ölçeği toplam puanları ile Sporda Ego ve Görev Yönelimi Ölçeği görev yönelimi ve ego yönelimi alt boyutları toplam puanları bağımsız örneklem testi sonuçları

\begin{tabular}{|c|c|c|c|c|c|c|c|}
\hline & Grup & $\mathbf{N}$ & Ortalama & $\begin{array}{l}\text { Standart } \\
\text { Sapma }\end{array}$ & $\mathbf{t}$ & $\begin{array}{c}\text { Serbestlik } \\
\text { Derecesi }\end{array}$ & $\mathbf{p}$ \\
\hline \multirow{2}{*}{$\begin{array}{l}\text { HÖYÖ Fiziksel Yeterlik Alt Boyut } \\
\text { Toplam Puanı }\end{array}$} & Kadın & 129 & 4.44 & .61 & \multirow{2}{*}{2.200} & \multirow{2}{*}{251.64} & \multirow{2}{*}{.029} \\
\hline & Erkek & 143 & 4.60 & .52 & & & \\
\hline \multirow{2}{*}{$\begin{array}{l}\text { HÖYÖ Oyun Bilgisi Alt Boyut Toplam } \\
\text { Puanı }\end{array}$} & Kadın & 129 & 4.58 & .64 & \multirow{2}{*}{ - } & \multirow{2}{*}{ - } & \multirow{2}{*}{-} \\
\hline & Erkek & 143 & 4.63 & .50 & & & \\
\hline \multirow{2}{*}{$\begin{array}{l}\text { HÖYö Karar Verme Alt Boyut Toplam } \\
\text { Puanı }\end{array}$} & Kadın & 129 & 4.32 & .65 & \multirow{2}{*}{$3 . \overline{4} 36$} & \multirow{2}{*}{237.04} & \multirow{2}{*}{.001} \\
\hline & Erkek & 143 & 4.56 & .49 & & & \\
\hline \multirow{2}{*}{$\begin{array}{l}\text { Hakem Öz Yeterlik Ölçeği Baskı Alt } \\
\text { Boyut Toplam Puanı }\end{array}$} & Kadın & 129 & 4.39 & .77 & \multirow{2}{*}{$\begin{array}{c}- \\
1.774\end{array}$} & \multirow{2}{*}{270} & \multirow{2}{*}{.077} \\
\hline & Erkek & 143 & 4.54 & .67 & & & \\
\hline \multirow{2}{*}{$\begin{array}{l}\text { Hakem Öz Yeterlik Ölçeği İletişim Alt } \\
\text { Boyut Toplam Puanı }\end{array}$} & Kadın & 129 & 4.60 & .60 & \multirow{2}{*}{.293} & \multirow{2}{*}{270} & \multirow{2}{*}{.769} \\
\hline & Erkek & 143 & 4.58 & .48 & & & \\
\hline \multirow[b]{2}{*}{ HÖYÖ Toplam Puanı } & Kadın & 129 & 4.47 & .54 & \multirow{2}{*}{$1 . \overline{9} 1$} & \multirow[b]{2}{*}{237.598} & \multirow[b]{2}{*}{.055} \\
\hline & Erkek & 143 & 4.58 & .41 & & & \\
\hline \multirow{2}{*}{$\begin{array}{l}\text { SGEYÖ Görev Yönelimi Alt Boyutu } \\
\text { Toplam Puanı }\end{array}$} & Kadın & 129 & 4.13 & .66 & \multirow{2}{*}{.458} & \multirow{2}{*}{.271} & \multirow{2}{*}{.648} \\
\hline & Erkek & 143 & 4.10 & .72 & & & \\
\hline $\begin{array}{l}\text { SGEYÖ Ego Yönelimi Alt Boyutu Toplam } \\
\text { Puanı }\end{array}$ & Kadın & 129 & 3.36 & .98 & .192 & 271 & .848 \\
\hline
\end{tabular}


Hakem öz yeterliğinin fiziksel yeterlik alt boyutu toplam puan ortalamaları arasında cinsiyet grupları için istatistiksel olarak anlamlı bir fark vardır. Erkek hakemlerin, kadın hakemlere göre fiziksel alt boyut puanları daha yüksektir. Hakem öz yeterlik ölçeği oyun bilgisi alt boyutu toplam puan ortalamaları arasında cinsiyet grupları için istatistiksel olarak anlamlı bir fark yoktur. Hakem öz yeterlik ölçeği karar verme alt boyutu toplam puan ortalamaları arasında cinsiyet grupları için istatistiksel olarak anlamlı bir fark vardır. Erkek hakemlerin kadın hakemlere göre karar verme alt boyutu toplam puanları daha yüksektir. Hakem öz yeterlik ölçeği baskı alt boyutu toplam puan ortalamaları arasında cinsiyet grupları için istatistiksel olarak anlamlı bir fark yoktur. Hakem öz yeterlik ölçeği iletișim alt boyutu toplam puan ortalamaları arasında cinsiyet grupları için istatistiksel olarak anlamlı bir fark yoktur. Hakem öz yeterlik ölçeği toplam puan ortalamaları arasında cinsiyet grupları için istatistiksel olarak anlamlı bir fark yoktur. Sporda görev ve ego yönelimi ölçeği görev yönelimi alt boyut toplam puan ortalamaları arasında cinsiyet grupları için anlamlı bir fark yoktur. Sporda görev ve ego yönelimi ölçeği görev yönelimi alt boyut toplam puan ortalamaları arasında cinsiyet grupları için anlamlı bir fark yoktur. Sporda görev ve ego yönelimi ölçeği ego yönelimi alt boyut toplam puan ortalamaları arasında cinsiyet grupları için anlamlı bir fark yoktur.

Meslek Grupları Açısından Hakem Öz Yeterlik Ölçeği Fiziksel Yeterlik, Oyun Bilgisi, Karar Verme, Baskı, İletişim Alt Boyutları ve Hakem Öz Yeterlik Ölçeği Toplam Puanları ile Sporda Ego ve Görev Yönelimi Ölçeği Görev Yönelimi ve Ego Yönelimi Alt Boyutları Toplam Puan Ortalamalarının Tek Yönlü Varyans Analizi (ANOVA) ile Karşılaştırma Sonuçlarına bakıldığında anlamlı bir farklılığa rastlanmamıştır.

\section{Tablo 3}

Yaş grupları açısından Hakem Öz Yeterlik Ölçeği fiziksel yeterlik, oyun bilgisi, karar verme, baskı, iletişim alt boyutları ve hakem öz yeterlik ölçeği toplam puanları ile Sporda Ego Ve Görev Yönelimi Ölçeği görev yönelimi ve ego yönelimi alt boyutları toplam puan ortalamalarının Tek Yönlü Varyans Analizi (ANOVA) ile karşılaștırma sonuçları

\begin{tabular}{|c|c|c|c|c|}
\hline & Yaş & $\begin{array}{l}\text { Kişi Sayısı } \\
\text { (n) }\end{array}$ & Ortalama & $\begin{array}{c}\text { Standart } \\
\text { Sapma }\end{array}$ \\
\hline \multirow{6}{*}{$\begin{array}{l}\text { Hakem Öz Yeterlik Ölçeği Fiziksel Yeterlik Alt Boyut } \\
\text { Toplam Puanı }\end{array}$} & 18-25 Yaș & 101 & 4.54 & .58 \\
\hline & 26-33 Yaș & 75 & 4.52 & .52 \\
\hline & 34-41 Yaş & 45 & 4.63 & .50 \\
\hline & 42-49 Yaş & 25 & 4.33 & .76 \\
\hline & $\begin{array}{c}50 \text { yaş ve } \\
\text { üzeri }\end{array}$ & 20 & 4.53 & .42 \\
\hline & Toplam & 266 & 4.53 & .56 \\
\hline \multirow{6}{*}{$\begin{array}{l}\text { Hakem Öz Yeterlik Ölçeği Oyun Bilgisi Alt Boyut Toplam } \\
\text { Puanı }\end{array}$} & 18-25 Yaş & 101 & 4.63 & .50 \\
\hline & 26-33 Yaș & 75 & 4.55 & .61 \\
\hline & 34-41 Yaş & 45 & 4.61 & .50 \\
\hline & 42-49 Yaş & 25 & 4.60 & .55 \\
\hline & $\begin{array}{c}50 \text { yaş ve } \\
\text { üzeri }\end{array}$ & 20 & 4.85 & .33 \\
\hline & Toplam & 266 & 4.62 & .53 \\
\hline
\end{tabular}


Voleybol Hakemlerinin Ego ve Görev Yönelimleri Bakımından Öz Yeterliklerinin Incelenmesi

\begin{tabular}{|c|c|c|c|c|}
\hline \multirow{5}{*}{$\begin{array}{l}\text { Hakem Öz Yeterlik Ölçeği Karar Verme Alt Boyut Toplam } \\
\text { Puanı }\end{array}$} & 18-25 Yaş & 101 & 4.35 & .56 \\
\hline & 26-33 Yaș & 75 & 4.36 & .58 \\
\hline & 34-41 Yaş & 45 & 4.62 & .52 \\
\hline & 42-49 Yaş & 25 & 4.58 & .48 \\
\hline & $\begin{array}{c}50 \text { yaş ve } \\
\text { üzeri }\end{array}$ & 20 & 4.70 & .56 \\
\hline \multirow{8}{*}{ Hakem Öz Yeterlik Ölçeği Baskı Alt Boyut Toplam Puanı } & Toplam & 266 & 4.45 & .56 \\
\hline & $18-25$ Yaș & 101 & 4.48 & .57 \\
\hline & 26-33 Yaș & 75 & 4.39 & .78 \\
\hline & 34-41 Yaş & 45 & 4.60 & .64 \\
\hline & 42-49 Yaș & 25 & 4.49 & .83 \\
\hline & $\begin{array}{c}50 \text { yaş ve } \\
\text { üzeri }\end{array}$ & 20 & 4.46 & .93 \\
\hline & Toplam & 266 & 4.47 & .70 \\
\hline & 18-25 Yaș & 101 & 4.61 & .49 \\
\hline \multirow{4}{*}{$\begin{array}{l}\text { Hakem Öz Yeterlik Ölçeği İletişim Alt Boyut Toplam } \\
\text { Puanı }\end{array}$} & 26-33 Yaș & 75 & 4.56 & .53 \\
\hline & 34-41 Yaş & 45 & 4.60 & .50 \\
\hline & 42-49 Yaş & 25 & 4.73 & .40 \\
\hline & $\begin{array}{c}50 \text { yaş ve } \\
\text { üzeri }\end{array}$ & 20 & 4.58 & .44 \\
\hline \multirow{7}{*}{ Hakem Öz Yeterlik Ölçeği Toplam Puanı } & Toplam & 266 & 4.60 & .49 \\
\hline & 18-25 Yaș & 101 & 4.53 & .43 \\
\hline & 26-33 Yaș & 75 & 4.48 & .46 \\
\hline & 34-41 Yaş & 45 & 4.61 & .43 \\
\hline & 42-49 Yaş & 25 & 4.53 & .52 \\
\hline & $\begin{array}{l}50 \text { yaş ve } \\
\text { üzeri }\end{array}$ & 20 & 4.61 & .40 \\
\hline & Toplam & 266 & 4.54 & .45 \\
\hline \multirow{5}{*}{$\begin{array}{l}\text { Sporda Görev ve Ego Yönelim Ölçeği Görev Yönelimi Alt } \\
\text { boyut Toplam Puanı }\end{array}$} & 18-25 Yaş & 102 & 4.14 & .71 \\
\hline & 26-33 Yaş & 75 & 4.10 & .63 \\
\hline & 34-41 Yaș & 45 & 4.22 & .76 \\
\hline & 42-49 Yaş & 25 & 3.88 & .78 \\
\hline & $\begin{array}{c}50 \text { yaş ve } \\
\text { üzeri }\end{array}$ & 20 & 4.07 & .57 \\
\hline \multirow{7}{*}{$\begin{array}{l}\text { Sporda Görev ve Ego Yönelim Ölçeği Ego Yönelimi Alt } \\
\text { boyut Toplam Puanı }\end{array}$} & Toplam & 267 & 4.11 & .69 \\
\hline & $18-25$ Yaș & 102 & 3.38 & .98 \\
\hline & 26-33 Yaş & 75 & 3.48 & .93 \\
\hline & 34-41 Yaş & 45 & 3.27 & 1.04 \\
\hline & 42-49 Yaş & 25 & 3.02 & .96 \\
\hline & $\begin{array}{c}50 \text { yaş ve } \\
\text { üzeri }\end{array}$ & 20 & 3.23 & .84 \\
\hline & Toplam & 267 & 3.35 & .97 \\
\hline
\end{tabular}

Nazlı Ekmekçi, Aylin Zekioğlu, Nihal Dal

\begin{tabular}{|c|c|c|c|c|c|}
\hline & & $\begin{array}{l}\text { Kareler } \\
\text { Toplamı }\end{array}$ & $\begin{array}{c}\text { Serbestlik } \\
\text { Derecesi }\end{array}$ & $\begin{array}{c}\text { Kareler } \\
\text { Ortalaması }\end{array}$ & $\mathbf{P}$ \\
\hline \multirow{3}{*}{$\begin{array}{l}\text { Hakem Öz Yeterlik Ölçeği Fiziksel Yeterlik Alt } \\
\text { Boyut Toplam Puanı }\end{array}$} & $\begin{array}{c}\text { Gruplar } \\
\text { Arası }\end{array}$ & 1.49 & 4 & .37 & 1.17.321 \\
\hline & Grup İçi & 82.91 & 261 & .31 & \\
\hline & Toplam & 84.41 & 265 & & \\
\hline \multirow{3}{*}{$\begin{array}{l}\text { Hakem Öz Yeterlik Ölçeği Oyun Bilgisi Alt Boyut } \\
\text { Toplam Puanı }\end{array}$} & $\begin{array}{l}\text { Gruplar } \\
\text { Arası }\end{array}$ & 1.39 & 4 & .35 & 1.22 .301 \\
\hline & Grup İçi & 74.50 & 261 & .28 & \\
\hline & Toplam & 75.90 & 265 & & \\
\hline $\begin{array}{l}\text { Hakem Öz Yeterlik Ölçeği Karar Verme Alt Boyut } \\
\text { Toplam Puanı }\end{array}$ & $\begin{array}{l}\text { Gruplar } \\
\text { Arası }\end{array}$ & 4.52 & 4 & 1.13 & 3.66 .006 \\
\hline
\end{tabular}




\begin{tabular}{|c|c|c|c|c|c|}
\hline & \multirow{2}{*}{$\begin{array}{l}\text { Grup İçi } \\
\text { Toplam }\end{array}$} & \multirow{2}{*}{$\frac{80.65}{85.17}$} & \multirow{2}{*}{$\frac{261}{265}$} & \multicolumn{2}{|l|}{.30} \\
\hline & & & & & \\
\hline \multirow{3}{*}{$\begin{array}{l}\text { Hakem Öz Yeterlik Ölçeği Baskı Alt Boyut Toplam } \\
\text { Puanı }\end{array}$} & $\begin{array}{l}\text { Gruplar } \\
\text { Arası }\end{array}$ & 1.16 & 4 & .29 & .58 .673 \\
\hline & Grup İçi & 129.63 & 261 & .49 & \\
\hline & Toplam & 130.80 & 265 & & \\
\hline \multirow{3}{*}{$\begin{array}{l}\text { Hakem Öz Yeterlik Ölçeği İletişim Alt Boyut } \\
\text { Toplam Puanı }\end{array}$} & $\begin{array}{l}\text { Gruplar } \\
\text { Arası }\end{array}$ & .55 & 4 & .13 & .56 .690 \\
\hline & Grup İçi & 64.62 & 261 & .24 & \\
\hline & Toplam & 65.17 & 265 & & \\
\hline \multirow{3}{*}{ Hakem Öz Yeterlik Ölçeği Toplam Puanı } & $\begin{array}{l}\text { Gruplar } \\
\text { Arası }\end{array}$ & .57 & 4 & .14 & .71 .585 \\
\hline & Grup İçi & 53.10 & 261 & .20 & \\
\hline & Toplam & 53.68 & 265 & & \\
\hline \multirow{3}{*}{$\begin{array}{l}\text { Sporda Görev ve Ego Yönelim Ölçeği Görev } \\
\text { Yönelimi Alt boyut Toplam Puanı }\end{array}$} & $\begin{array}{l}\text { Gruplar } \\
\text { Arası } \\
\end{array}$ & 1.99 & 4 & .49 & 1.02 .398 \\
\hline & Grup İçi & 128.00 & 262 & .48 & \\
\hline & Toplam & 129.99 & 266 & & \\
\hline \multirow{3}{*}{$\begin{array}{l}\text { Sporda Görev ve Ego Yönelim Ölçeği Ego Yönelimi } \\
\text { Alt boyut Toplam Puanı }\end{array}$} & $\begin{array}{l}\text { Gruplar } \\
\text { Arası }\end{array}$ & 4.72 & 4 & 1.18 & 1.25 .289 \\
\hline & Grup İçi & 247.42 & 262 & .94 & \\
\hline & Toplam & 252.15 & 266 & & \\
\hline
\end{tabular}

Yaş gruplarının Fiziksel Yeterlik alt boyutu toplam puan ortalamaları arasında istatistiksel olarak anlamlı bir fark yoktur; $F(4,261)=1,177 ; p>0,05$.Yaş gruplarının Oyun Bilgisi alt boyutu toplam puan ortalamaları arasında istatistiksel olarak anlamlı bir fark yoktur; $F(4,261)=1,225 ; p>0,05$. Yaş gruplarının Karar Verme alt boyutu toplam puan ortalamaları arasında istatistiksel olarak anlamlı bir fark vardır; $F(4,261)=3,660 ; p<0,05$

Hangi grubun hangi gruptan farklı olduğunu belirlemek için yapılan Tukey-B çoklu karşılaştırma ve LSD testi sonucuna göre 18-25 yaş grubu karar verme alt boyutu toplam puan ortalaması 34-41 yaş grubu karar verme alt boyutu toplam puan ortalamasından daha düşüktür. 18-25 grubunun Karar verme alt boyutu toplam puanı 50 ve üzeri yaş grubu Karar verme alt boyutu toplam puanından daha düşüktür. 26-33 yaş grubu karar verme alt boyutu toplam puan ortalaması 34-41 yaş grubu karar verme alt boyutu toplam puan ortalamasından daha düşüktür. 26-33 yaş grubu karar verme alt boyutu toplam puan ortalaması 50 ve üzeri yaş grubu karar verme alt boyutu toplam puan ortalamasından daha düşüktür.

Yaş gruplarının Baskı alt boyutu toplam puan ortalamaları arasında istatistiksel olarak anlamlı bir fark yoktur; $F(4,261)=0,587 ; p>0,05$. Yaş gruplarının İletişim alt boyutu toplam puan ortalamaları arasında istatistiksel olarak anlamlı bir fark yoktur; $F(4,261)=0,563 ; p>0,05$. Yaş gruplarının Hakem Öz Yeterlik Ölçeği genel toplam puan ortalamaları arasında istatistiksel olarak anlamlı bir fark yoktur; $F(4,261)=0,711 ; p>0,05$. 
Voleybol Hakemlerinin Ego ve Görev Yönelimleri Bakımından Öz Yeterliklerinin Incelenmesi

Yaş gruplarının Görev Yönelimi alt boyutu toplam puan ortalamaları arasında istatistiksel olarak anlamlı bir fark yoktur; $F(4,262)=1,020 ; p>0,05$. Yaş gruplarının Ego Yönelimi alt boyutu toplam puan ortalamaları arasında istatistiksel olarak anlamlı bir fark yoktur; $F(4,262)=1,252 ; p>0,05$.

\section{Tablo 4}

Deneyim grupları açısından Hakem Öz Yeterlik Ölçeği fiziksel yeterlik, oyun bilgisi, karar verme, baskl, iletişim alt boyutları ve hakem öz yeterlik ölçeği toplam puanları ile Sporda Ego Ve Görev Yönelimi Ölçeği görev yönelimi ve ego yönelimi alt boyutları toplam puan ortalamalarının Tek Yönlü Varyans Analizi (ANOVA) ile karşılaştırma sonuçları

\begin{tabular}{|c|c|c|c|c|}
\hline & Deneyim & $\begin{array}{l}\text { Kişi Sayısı } \\
(n)\end{array}$ & Ortalama & $\begin{array}{c}\text { Standart } \\
\text { Sapma }\end{array}$ \\
\hline \multirow{7}{*}{$\begin{array}{l}\text { Hakem Öz Yeterlik Ölçeği Fiziksel Yeterlik Alt Boyut Toplam } \\
\text { Puanı }\end{array}$} & $1-5$ yil & 135 & 4.54 & .58 \\
\hline & $6-10 \mathrm{yll}$ & 48 & 4.53 & .48 \\
\hline & $11-15$ yll & 35 & 4.65 & .48 \\
\hline & $16-20$ yll & 25 & 4.37 & .67 \\
\hline & $21-25$ yll & 11 & 4.27 & 72 \\
\hline & $\begin{array}{l}26 \text { yll ve } \\
\text { üzeri }\end{array}$ & 10 & 4.68 & .36 \\
\hline & Toplam & 264 & 4.53 & .56 \\
\hline \multirow{7}{*}{ Hakem Öz Yeterlik Ölçeği Oyun Bilgisi Alt Boyut Toplam Puanı } & $1-5$ yll & 135 & 4.58 & .55 \\
\hline & $6-10 \mathrm{yll}$ & 48 & 4.60 & .58 \\
\hline & $11-15 \mathrm{yll}$ & 35 & 4.69 & .46 \\
\hline & $16-20 \mathrm{yll}$ & 25 & 4.65 & .48 \\
\hline & $21-25 \mathrm{yll}$ & 11 & 4.57 & .57 \\
\hline & $\begin{array}{l}26 \text { yll ve } \\
\text { üzeri }\end{array}$ & 10 & 5.00 & .00 \\
\hline & Toplam & 264 & 4.62 & .53 \\
\hline \multirow{7}{*}{ Hakem Öz Yeterlik Ölçeği Karar Verme Alt Boyut Toplam Puanı } & $1-5$ yll & 135 & 4.37 & .57 \\
\hline & $6-10 \mathrm{yll}$ & 48 & 4.37 & .56 \\
\hline & $11-15$ yll & 35 & 4.65 & .51 \\
\hline & $16-20 \mathrm{yll}$ & 25 & 4.55 & .51 \\
\hline & $21-25 \mathrm{yll}$ & 11 & 4.66 & .59 \\
\hline & $\begin{array}{l}26 \text { yll ve } \\
\text { üzeri }\end{array}$ & 10 & 4.86 & .32 \\
\hline & Toplam & 264 & $4 . .45$ & .56 \\
\hline \multirow{7}{*}{ Hakem Öz Yeterlik Ölçeği Baskı Alt Boyut Toplam Puanı } & $1-5 \mathrm{yll}$ & 135 & 4.48 & .63 \\
\hline & 6-10 yll & 48 & 4.51 & .57 \\
\hline & $11-15 \mathrm{yll}$ & 35 & 4.50 & .86 \\
\hline & $16-20 \mathrm{yll}$ & 25 & 4.38 & .83 \\
\hline & $21-25$ yll & 11 & 4.24 & .17 \\
\hline & $\begin{array}{c}26 \text { yll ve } \\
\text { üzeri }\end{array}$ & 10 & 4.86 & .32 \\
\hline & Toplam & 264 & 4.48 & .69 \\
\hline \multirow{4}{*}{ Hakem Öz Yeterlik Ölçeği İletişim Alt Boyut Toplam Puanı } & $1-5$ yll & 135 & 4.61 & .52 \\
\hline & $6-10 \mathrm{yll}$ & 48 & 4.53 & .49 \\
\hline & $11-15$ yll & 35 & 4.61 & .48 \\
\hline & $16-20$ yll & 25 & 4.74 & .37 \\
\hline
\end{tabular}


Voleybol Hakemlerinin Ego ve Görev Yönelimleri Bakımından Öz Yeterliklerinin Incelenmesi

Nazlı Ekmekçi, Aylin Zekioğlu, Nihal Dal

Hakem Öz Yeterlik Ölçeği Toplam Puanı

\begin{tabular}{|c|c|c|c|}
\hline $21-25$ yll & 11 & 4.56 & .51 \\
\hline $\begin{array}{c}26 \text { yll ve } \\
\text { üzeri }\end{array}$ & 10 & 4.62 & .37 \\
\hline Toplam & 264 & 4.60 & .49 \\
\hline $1-5$ yll & 135 & 4.52 & .47 \\
\hline 6-10 yll & 48 & 4.51 & .38 \\
\hline $11-15$ yll & 35 & 4.62 & .42 \\
\hline $16-20$ yll & 25 & 4.53 & .47 \\
\hline $21-25$ yll & 11 & 4.44 & .52 \\
\hline $\begin{array}{c}26 \text { yll ve } \\
\text { üzeri }\end{array}$ & 10 & 4.78 & .26 \\
\hline Toplam & 264 & 4.54 & .44 \\
\hline $1-5$ yll & 137 & 4.13 & .67 \\
\hline 6-10 yll & 47 & 4.03 & .76 \\
\hline $11-15$ yll & 35 & 4.21 & .81 \\
\hline $16-20$ yll & 25 & 4.02 & .62 \\
\hline 21-25 yll & 11 & 3.88 & .45 \\
\hline $\begin{array}{c}26 \text { yll ve } \\
\text { üzeri }\end{array}$ & 10 & 4.12 & .71 \\
\hline Toplam & 265 & 4.10 & .70 \\
\hline $1-5 \mathrm{yll}$ & 137 & 3.44 & .98 \\
\hline 6-10 yll & 47 & 3.28 & .88 \\
\hline $11-15$ yll & 35 & 3.14 & 1.04 \\
\hline $16-20$ yll & 25 & 3.23 & .98 \\
\hline $21-25$ yll & 11 & 2.90 & .98 \\
\hline $\begin{array}{c}26 \text { yll ve } \\
\text { üzeri }\end{array}$ & 10 & 3.33 & .80 \\
\hline Toplam & 265 & 3.33 & .97 \\
\hline
\end{tabular}

Sporda Görev ve Ego Yönelim Ölçeği Görev Yönelimi Alt boyut Toplam Puanı

Sporda Görev ve Ego Yönelim Ölçeği Ego Yönelimi Alt boyut Toplam Puanı

\begin{tabular}{|c|c|c|c|c|}
\hline & \multirow{2}{*}{$\begin{array}{c}26 \text { yll ve } \\
\text { üzeri } \\
\text { Toplam }\end{array}$} & 10 & 4.12 & .71 \\
\hline & & 265 & 4.10 & .70 \\
\hline \multirow{7}{*}{$\begin{array}{l}\text { Sporda Görev ve Ego Yönelim Ölçeği Ego Yönelimi Alt boyut } \\
\text { Toplam Puanı }\end{array}$} & $1-5$ yll & 137 & 3.44 & .98 \\
\hline & 6-10 yll & 47 & 3.28 & .88 \\
\hline & 11-15 yll & 35 & 3.14 & 1.04 \\
\hline & 16-20 yll & 25 & 3.23 & .98 \\
\hline & $21-25$ yll & 11 & 2.90 & .98 \\
\hline & $\begin{array}{c}26 \text { yll ve } \\
\text { üzeri }\end{array}$ & 10 & 3.33 & .80 \\
\hline & Toplam & 265 & 3.33 & .97 \\
\hline
\end{tabular}

\begin{tabular}{|c|c|c|c|c|c|}
\hline & & $\begin{array}{l}\text { Kareler } \\
\text { Toplamı }\end{array}$ & $\begin{array}{l}\text { Serbestlik } \\
\text { Derecesi }\end{array}$ & $\begin{array}{c}\text { Kareler } \\
\text { Ortalaması }\end{array}$ & $\mathbf{F} \quad \mathbf{P}$ \\
\hline \multirow{3}{*}{$\begin{array}{l}\text { Hakem Öz Yeterlik Ölçeği Fiziksel Yeterlik Alt } \\
\text { Boyut Toplam Puanı }\end{array}$} & $\begin{array}{l}\text { Gruplar } \\
\text { Arası }\end{array}$ & 2.10 & 5 & .42 & 1.32 .256 \\
\hline & Grup İçi & 82.23 & 258 & .31 & \\
\hline & Toplam & 84.33 & 263 & & \\
\hline \multirow{3}{*}{$\begin{array}{l}\text { Hakem Öz Yeterlik Ölçeği Oyun Bilgisi Alt Boyut } \\
\text { Toplam Puanı }\end{array}$} & $\begin{array}{l}\text { Gruplar } \\
\text { Arası }\end{array}$ & 1.83 & 5 & .36 & 1.29 .266 \\
\hline & Grup İçi & 73.16 & 258 & .28 & \\
\hline & Toplam & 75.00 & 263 & & \\
\hline \multirow{3}{*}{$\begin{array}{l}\text { Hakem Öz Yeterlik Ölçeği Karar Verme Alt Boyut } \\
\text { Toplam Puanı }\end{array}$} & $\begin{array}{l}\text { Gruplar } \\
\text { Arası }\end{array}$ & 5.10 & 5 & 1.02 & 3.29 .007 \\
\hline & Grup İçi & 79.93 & 258 & .31 & \\
\hline & Toplam & 85.04 & 263 & & \\
\hline \multirow{3}{*}{$\begin{array}{l}\text { Hakem Öz Yeterlik Ölçeği Baskı Alt Boyut Toplam } \\
\text { Puanı }\end{array}$} & $\begin{array}{l}\text { Gruplar } \\
\text { Arası }\end{array}$ & 2.38 & 5 & .47 & .97 .433 \\
\hline & Grup İçi & 126.22 & 258 & .48 & \\
\hline & Toplam & 128.60 & 263 & & \\
\hline
\end{tabular}




\begin{tabular}{|c|c|c|c|c|c|}
\hline \multirow{3}{*}{$\begin{array}{l}\text { Hakem Öz Yeterlik Ölçeği İletişim Alt Boyut } \\
\text { Toplam Puanı }\end{array}$} & $\begin{array}{c}\text { Gruplar } \\
\text { Arası }\end{array}$ & .70 & 5 & .14 & .57 .722 \\
\hline & \multirow{2}{*}{$\begin{array}{l}\text { Grup İçi } \\
\text { Toplam }\end{array}$} & 63.60 & 258 & .24 & \\
\hline & & 64.30 & 263 & & \\
\hline \multirow{3}{*}{ Hakem Öz Yeterlik Ölçeği Toplam Puanı } & $\begin{array}{l}\text { Gruplar } \\
\text { Arası }\end{array}$ & .98 & 5 & .19 & .98 .429 \\
\hline & \multirow{2}{*}{$\begin{array}{l}\text { Grup İçi } \\
\text { Toplam }\end{array}$} & 51.92 & 258 & .20 & \\
\hline & & 52.90 & 263 & & \\
\hline \multirow{3}{*}{$\begin{array}{l}\text { Sporda Görev ve Ego Yönelim Ölçeği Görev } \\
\text { Yönelimi Alt boyut Toplam Puanı }\end{array}$} & $\begin{array}{l}\text { Gruplar } \\
\text { Arası }\end{array}$ & 1.54 & 5 & .30 & .62 .681 \\
\hline & \multirow{2}{*}{$\begin{array}{l}\text { Grup İçi } \\
\text { Toplam }\end{array}$} & 127.91 & 259 & .49 & \\
\hline & & 129.45 & 264 & & \\
\hline \multirow{3}{*}{$\begin{array}{l}\text { Sporda Görev ve Ego Yönelim Ölçeği Ego } \\
\text { Yönelimi Alt boyut Toplam Puanı }\end{array}$} & $\begin{array}{l}\text { Gruplar } \\
\text { Arası }\end{array}$ & 5.28 & 5 & 1.05 & 1.12347 \\
\hline & Grup İçi & 243.27 & 259 & .93 & \\
\hline & Toplam & 248.56 & 264 & & \\
\hline
\end{tabular}

Deneyim gruplarının Fiziksel Yeterlik alt boyutu toplam puan ortalamaları arasında istatistiksel olarak anlamlı bir fark yoktur; $F(5,258)=1,321 ; p>0,05$. Deneyim gruplarının Oyun Bilgisi alt boyutu toplam puan ortalamaları arasında istatistiksel olarak anlamlı bir fark yoktur; $F(5,258)=1,296 ; p>0,05$. Deneyim gruplarının Karar Verme alt boyutu toplam puan ortalamaları arasında istatistiksel olarak anlamlı bir fark vardır; $F(5,258)=3,295 ; p<0,05$. Hangi grubun hangi gruptan farklı olduğunu belirlemek için yapılan Tukey-B çoklu karşılaştırma testi sonucuna göre;

1-5 yll deneyim grubunun karar verme alt boyutu toplam puan ortalaması, 11-15 yll, 16-20 yll, 21-25 yıl ve 26 yll ve üzeri deneyim grubu karar verme alt boyutu toplam puan ortalamasında daha düşüktür. 6-10 yıl deneyim grubunun karar verme alt boyutu toplam puan ortalaması 11-15 yll, 16-20 yll, 21-25 yll ve 26 yll ve üzeri deneyim grubu karar verme alt boyutu toplam puan ortalamasında daha düşüktür. 16-20 yll deneyim grubunun karar verme alt boyutu toplam puan ortalaması 1-5 yıl ve 6-10 yıl deneyim grubundan yüksek iken, 11-15 yll, 21-25 yıl ve 26 yll ve üzeri deneyim grubundan daha düşüktür. 11-15 yıl deneyim grubunun karar verme alt boyutu toplam puan ortalaması 16-20 yıl, 6-10 yll, 1-5 yıl deneyim grubundan yüksek iken, 21,25 yıl ve 26 yll ve üzeri deneyim grubundan daha düşüktür.

21-25 yıl deneyim grubunun karar verme alt boyutu toplam puan ortalaması 1-5 yll, 6-10 yll, 16-20 yll ve 11-15 yll deneyim grubu yüksek iken, 26 yıl ve üzeri deneyim grubundan daha düşüktür. 26 yıl ve üzeri deneyim grubu karar verme alt boyutu toplam puan ortalaması 1-5 yll, 6-10 yıl, 16-20 yll, 11-15 yll ve 21-25 yıl deneyim grubundan daha yüksektir. Deneyim gruplarının Baskı alt boyutu toplam puan ortalamaları arasında istatistiksel olarak anlamlı bir fark yoktur; $F(5,258)=0,976 ; p>0,05$. Deneyim gruplarının İletişim alt boyutu toplam puan ortalamaları arasında istatistiksel olarak anlamlı bir fark yoktur; $F(5,258)=0,571 ; p>0,05$. Deneyim gruplarının Hakem Öz Yeterlik Ölçeği genel toplam puan ortalamaları arasında istatistiksel olarak 
Voleybol Hakemlerinin Ego ve Görev Yönelimleri Bakımından Öz Yeterliklerinin İncelenmesi

anlamlı bir fark yoktur; $F(5,258)=0,982 ; p>0,05$. Deneyim gruplarının Görev Yönelimi alt boyutu toplam puan ortalamaları arasında istatistiksel olarak anlamlı bir fark yoktur; $F(5,259)=0,625 ; p>0,05$. Deneyim gruplarının Ego Yönelimi alt boyutu toplam puan ortalamaları arasında istatistiksel olarak anlamlı bir fark yoktur; $F(5,259)=1,125 ; p>0,05$.

\section{Tablo 5}

Klasman grupları açısından Hakem Öz Yeterlik Ölçeği fiziksel yeterlik, oyun bilgisi, karar verme, baskl, iletişim alt boyutları ve hakem öz yeterlik ölçeği toplam puanları ile Sporda Ego Ve Görev Yönelimi Ölçeği görev yönelimi ve ego yönelimi alt boyutları toplam puan ortalamalarının Tek Yönlü Varyans Analizi (ANOVA) ile karşılaştırma sonuçları

\begin{tabular}{|c|c|c|c|c|}
\hline & Klasman & $\begin{array}{l}\text { Kişi Sayısı } \\
\text { (n) }\end{array}$ & Ortalama & $\begin{array}{l}\text { Standart } \\
\text { Sapma }\end{array}$ \\
\hline \multirow{5}{*}{$\begin{array}{l}\text { Hakem Öz Yeterlik Ölçeği Fiziksel Yeterlik Alt Boyut Toplam } \\
\text { Puanı }\end{array}$} & Aday & 73 & 4.49 & .66 \\
\hline & İl & 88 & 4.54 & .50 \\
\hline & Ulusal & 104 & 4.53 & .54 \\
\hline & Uluslararası & 5 & 4.80 & .34 \\
\hline & Toplam & 270 & 4.53 & .56 \\
\hline \multirow{5}{*}{ Hakem Öz Yeterlik Ölçeği Oyun Bilgisi Alt Boyut Toplam Puanı } & Aday & 73 & 4.56 & .58 \\
\hline & İl & 88 & 4.61 & .53 \\
\hline & Ulusal & 104 & 4.66 & .50 \\
\hline & Uluslararası & 5 & 5.00 & .00 \\
\hline & Toplam & 270 & 4.62 & .53 \\
\hline \multirow{5}{*}{ Hakem Öz Yeterlik Ölçeği Karar Verme Alt Boyut Toplam Puanı } & Aday & 73 & 4.33 & .57 \\
\hline & İl & 88 & 4.42 & .56 \\
\hline & Ulusal & 104 & 4.55 & .54 \\
\hline & Uluslararası & 5 & 5.00 & .00 \\
\hline & Toplam & 270 & 4.46 & .56 \\
\hline \multirow{5}{*}{ Hakem Öz Yeterlik Ölçeği Baskı Alt Boyut Toplam Puanı } & Aday & 73 & 4.52 & .60 \\
\hline & İl & 88 & 4.45 & .75 \\
\hline & Ulusal & 104 & 4.48 & .72 \\
\hline & Uluslararası & 5 & 5.00 & .00 \\
\hline & Toplam & 270 & 4.49 & .69 \\
\hline \multirow{5}{*}{ Hakem Öz Yeterlik Ölçeği İletişim Alt Boyut Toplam Puanı } & Aday & 73 & 4.58 & .55 \\
\hline & İl & 88 & 4.6 & .47 \\
\hline & Ulusal & 104 & 4.60 & .48 \\
\hline & Uluslararası & 5 & 4.60 & .41 \\
\hline & Toplam & 270 & 4.60 & .49 \\
\hline \multirow{5}{*}{ Hakem Öz Yeterlik Ölçeği Toplam Puanı } & Aday & 73 & 4.50 & .50 \\
\hline & İl & 88 & 4.53 & .42 \\
\hline & Ulusal & 104 & 4.56 & .43 \\
\hline & Uluslararası & 5 & 4.85 & .14 \\
\hline & Toplam & 270 & 4.54 & .44 \\
\hline \multirow{5}{*}{$\begin{array}{l}\text { Sporda Görev ve Ego Yönelim Ölçeği Görev Yönelimi Alt boyut } \\
\text { Toplam Puanı }\end{array}$} & Aday & 73 & 4.10 & .62 \\
\hline & İl & 89 & 4.14 & .78 \\
\hline & Ulusal & 104 & 4.10 & .67 \\
\hline & Uluslararası & 5 & 4.02 & .47 \\
\hline & Toplam & 271 & 4.11 & .69 \\
\hline \multirow{5}{*}{$\begin{array}{l}\text { Sporda Görev ve Ego Yönelim Ölçeği Ego Yönelimi Alt boyut } \\
\text { Toplam Puanı }\end{array}$} & Aday & 73 & 3.40 & .88 \\
\hline & İl & 89 & 3.52 & 1.06 \\
\hline & Ulusal & 104 & 3.18 & .912 \\
\hline & Uluslararası & 5 & 2.63 & .88 \\
\hline & Toplam & 271 & 3.34 & .97 \\
\hline
\end{tabular}




\begin{tabular}{|c|c|c|c|c|c|}
\hline & & $\begin{array}{l}\text { Kareler } \\
\text { Toplamı }\end{array}$ & $\begin{array}{c}\text { Serbestlik } \\
\text { Derecesi }\end{array}$ & $\begin{array}{c}\text { Kareler } \\
\text { Ortalaması }\end{array}$ & $\mathbf{F} \quad \mathbf{P}$ \\
\hline \multirow{3}{*}{$\begin{array}{l}\text { Hakem Öz Yeterlik Ölçeği Fiziksel Yeterlik Alt } \\
\text { Boyut Toplam Puanı }\end{array}$} & $\begin{array}{l}\text { Gruplar } \\
\text { Arası }\end{array}$ & .460 & 3 & .15 & .47 .698 \\
\hline & Grup İçi & 85.21 & 266 & .32 & \\
\hline & Toplam & 85.66 & 269 & & \\
\hline \multirow{3}{*}{$\begin{array}{l}\text { Hakem Öz Yeterlik Ölçeği Oyun Bilgisi Alt Boyut } \\
\text { Toplam Puanı }\end{array}$} & $\begin{array}{l}\text { Gruplar } \\
\text { Arası }\end{array}$ & 1.15 & 3 & .38 & 1.36 .255 \\
\hline & Grup İçi & 75.32 & 266 & .28 & \\
\hline & Toplam & 76.48 & 269 & & \\
\hline \multirow{3}{*}{$\begin{array}{l}\text { Hakem Öz Yeterlik Ölçeği Karar Verme Alt Boyut } \\
\text { Toplam Puanı }\end{array}$} & $\begin{array}{l}\text { Gruplar } \\
\text { Arası }\end{array}$ & 3.62 & 3 & 1.20 & 3.91 .009 \\
\hline & Grup İçi & 82.14 & 266 & .30 & \\
\hline & Toplam & 85.76 & 269 & & \\
\hline \multirow{3}{*}{$\begin{array}{l}\text { Hakem Öz Yeterlik Ölçeği Baskı Alt Boyut Toplam } \\
\text { Puanı }\end{array}$} & $\begin{array}{l}\text { Gruplar } \\
\text { Arası }\end{array}$ & 1.50 & 3 & .50 & 1.03 .380 \\
\hline & Grup İçi & 129.94 & 266 & .48 & \\
\hline & Toplam & 131.45 & 269 & & \\
\hline \multirow{3}{*}{$\begin{array}{l}\text { Hakem Öz Yeterlik Ölçeği İletişim Alt Boyut } \\
\text { Toplam Puanı }\end{array}$} & $\begin{array}{l}\text { Gruplar } \\
\text { Arası }\end{array}$ & .05 & 3 & .19 & .07 .973 \\
\hline & Grup İçi & 66.84 & 266 & .25 & \\
\hline & Toplam & 66.90 & 269 & & \\
\hline \multirow{3}{*}{ Hakem Öz Yeterlik Ölçeği Toplam Puanı } & $\begin{array}{l}\text { Gruplar } \\
\text { Arası }\end{array}$ & .64 & 3 & .21 & 1.07.361 \\
\hline & Grup İçi & 53.51 & 266 & .20 & \\
\hline & Toplam & 54.16 & 269 & & \\
\hline \multirow{3}{*}{$\begin{array}{l}\text { Sporda Görev ve Ego Yönelim Ölçeği Görev } \\
\text { Yönelimi Alt boyut Toplam Puanı }\end{array}$} & $\begin{array}{l}\text { Gruplar } \\
\text { Arası }\end{array}$ & .10 & 3 & .03 & .07 .976 \\
\hline & Grup İçi & 131.11 & 267 & .49 & \\
\hline & Toplam & 131.22 & 270 & & \\
\hline \multirow{3}{*}{$\begin{array}{l}\text { Sporda Görev ve Ego Yönelim Ölçeği Ego } \\
\text { Yönelimi Alt boyut Toplam Puanı }\end{array}$} & $\begin{array}{c}\text { Gruplar } \\
\text { Arası }\end{array}$ & 8.50 & 3 & 2.83 & 3.07 .028 \\
\hline & Grup İçi & 245.82 & 267 & .92 & \\
\hline & Toplam & 254.33 & 270 & & \\
\hline
\end{tabular}

Klasman gruplarının fiziksel yeterlik alt boyutu toplam puan ortalamaları arasında istatistiksel olarak anlamlı bir fark yoktur; $F(3,266)=0,478 ; p>0,05$. Klasman gruplarının oyun bilgisi alt boyutu toplam puan ortalamaları arasında istatistiksel olarak anlamlı bir fark yoktur; $F(3,266)=1,362 ; p>0,05$. Klasman gruplarının karar verme alt boyutu toplam puan ortalamaları arasında istatistiksel olarak anlamlı bir fark vardır; 
$\mathrm{F}(3,266)=3,912 ; \mathrm{p}<0,05$. Hangi grubun hangi gruptan farklı olduğunu belirlemek için yapılan Tukey-B çoklu karşılaştırma testi sonucuna göre Uluslararası klasman grubunun karar Verme alt boyutu toplam puan ortalaması aday klasman grubu puan ortalamasından daha yüksektir. Uluslararası klasman grubunun karar Verme alt boyutu toplam puan ortalaması il klasman grubu puan ortalamasından daha yüksektir. Uluslararası klasman grubunun karar verme alt boyutu toplam puan ortalaması ulusal klasman grubu puan ortalamasından daha yüksektir. Klasman gruplarının Baskı alt boyutu toplam puan ortalamaları arasında istatistiksel olarak anlamlı bir fark yoktur; $F(3,266)=1,030 ; p>0,05$. Klasman gruplarının İletişim alt boyutu toplam puan ortalamaları arasında istatistiksel olarak anlamlı bir fark yoktur; $F(3,266)=0,075 ; p>0,05$. Klasman gruplarının Hakem Öz Yeterlik Ölçeği genel toplam puan ortalamaları arasında istatistiksel olarak anlamlı bir fark yoktur; $F(3,266)=1,073 ; p>0,05$. Klasman gruplarının Görev Yönelimi alt boyutu toplam puan ortalamaları arasında istatistiksel olarak anlamlı bir fark yoktur; $F(3,267)=0,070$; $>00,05$. Klasman gruplarının Ego Yönelimi alt boyutu toplam puan ortalamaları arasında istatistiksel olarak anlamlı bir fark vardır; $F(3,267)=3,079 ; p<0,05$.

Hangi grubun hangi gruptan farklı olduğunu belirlemek için yapılan Tukey-B çoklu karşılaştırma testi sonucuna göre;

Uluslararası klasman grubunun ego yönelimi alt boyutu toplam puan ortalaması ulusal, aday ve il klasman grubu ego yönelimi alt boyutu toplam puan ortalamasından daha düşüktür. Ulusal klasman grubunun ego yönelimi alt boyutu toplam puan ortalaması aday ve il klasman grubundan düşük iken uluslararası klasman grubunun ego yönelimi alt boyutu toplam puan ortalamasından daha yüksektir. Aday klasman grubunun ego yönelimi alt boyutu toplam puan ortalaması il klasman grubundan düşük iken uluslararası ve ulusal klasman grubunun ego yönelimi alt boyutu toplam puan ortalamasından daha yüksektir. İl klasman grubunun ego yönelimi alt boyutu toplam puan ortalaması uluslararası, ulusal ve aday klasman grubundan daha yüksektir.

Şehir Grupları Açısından Hakem Öz Yeterlik Ölçeği Fiziksel Yeterlik, Oyun Bilgisi, Karar Verme, Baskı, İletişim Alt Boyutları ve Hakem Öz Yeterlik Ölçeği Toplam Puanları ile Sporda Ego ve Görev Yönelimi Ölçeği Görev Yönelimi ve Ego Yönelimi Alt Boyutları Toplam Puan Ortalamalarının Tek Yönlü Varyans Analizi (ANOVA) ile Karşılaştırma Sonuçlarına bakıldığında anlamlı bir farka rastlanmamıştır.

\section{TARTIŞMA, SONUÇ VE ÖNERİLER}

$\mathrm{Bu}$ çalışmanın amacı araştırmadan elde edilen sonuçlar çerçevesinde sporun bir parçası olan hakemlerin öz yeterlik düzeylerinin hedef yönelimler açısından incelenerek çıkan sonuçların birbirleri ile ilişkisi sonucunda hakemlere katkı sağlaması ve hakemlerin öz yeterliklerine etki eden hedef yönelimlerin bulunması ve bunları etkileme olasılığı bulunan faktörleri kontrol altına alabilmektir.

Ego ve görev yönelimi ve öz yeterlikle ile ilgili yapılan birçok araştırma olmasına rağmen hatta diğer branşlardaki hakemler üzerine yapılan çalışmalarda görülmüş ancak voleybol hakemleri üzerinde yapılan literatür taramaları sonucunda bu alanda sınırlı sayıda çalışma olduğu ve bu alanın hala incelendiği 
söyleyebiliriz. Bu çalıșma ile alanda literatüre yeni bilgiler kazandırılmaya ve halihazırda var olan bilgiler yenileriyle desteklenmeye çalışılmıştır.

Hakem öz yeterlik ölçeği alt boyutları fiziksel yeterlik, oyun bilgisi, karar verme, baskı, iletişim, HÖYÖ toplam puanı ve SEGYÖ görev yönelimi alt boyutunun her birinin birbiriyle arasında anlamlı bir ilişki olduğu sonucuna ulaşılmıştır. Ancak Sporda ego ve görev yönelimi ölçeği ego yönelimi alt boyutu sadece görev yönelimi alt boyutu ile arasında anlamlı bir ilişki bulunmuştur. En yüksek ilişkinin HÖYÖ toplam puanı ile oyun bilgisi alt boyutu arasında olduğu bulunurken en düşük ilişki ise SEGYÖ görev yönelimi alt boyutu ile baskı arasında bulunmuştur. HÖYÖ'nün kendi içerisindeki en düşük ilişki baskı ve fiziksel yeterlik alt boyutları arasında olduğu sonucuna ulaşılmıştır. Bu sonuçla voleybol hakemlerinin baskı altında kalsalar da kondisyonlarıyla ya da duruşlarıyla ilgili olumsuz bir düşünceye sahip olmadıklarını düşünebiliriz.

Çalışmamızda cinsiyet gruplarına göre hakem öz yeterlik ölçeği fiziksel yeterlik alt boyutu ve karar verme alt boyutu toplam puan ortalamaları için istatistiksel olarak anlamlı bir fark vardır. Erkek hakemlerin, kadın hakemlere göre fiziksel yeterlik ve karar verme alt boyut puanları daha yüksektir. Karaçam ve Pulur (2017) basketbol hakemleri üzerinde yaptıkları çalışmada bizim çalışmamıza uygun olarak fiziksel yeterlik ve karar verme düzeyleri erkek hakemlerin kadın hakemlere göre daha yüksek çıkmıştır. Yapılan bu çalışma birbirleriyle paralellik göstermektedir. Arslanoğlu vd., (2010) voleybol hakemlerinin temel psikolojik ihtiyaçlarını cinsiyet değişkenine göre incelemiş ve temel psikolojik ihtiyaçların içerisindeki yeterlik ihtiyacı arasında anlamlı bir farklılık olduğu sonucuna ulaşmıştır. Bu çalışmada bulguları sonucunda kendi çalışmamızdan farklı olarak bayan voleybol hakemlerinin erkek voleybol hakemlerine göre kendilerini daha yeterli hissettikleri sonucuna varılmaktadır.

Hakem öz yeterlik ölçeği baskı, iletişim alt boyutu toplam puan ortalamaları ve ölçek toplam puan ortalamaları arasında cinsiyet grupları için istatistiksel olarak anlamlı bir fark yoktur. Çalışmamıza uygun olarak Karaçam ve Pulur (2017) futbol, basketbol ve hentbol hakemleri üzerinde yapmış olduğu çalışmada da baskı, iletişim ve genel öz yeterlik düzeyleri arasında cinsiyetlere göre anlamlı bir fark bulunamamıştır. Aynı zamanda yine Karaçam ve Pulur (2017) basketbol hakemleri üzerine yapmış olduğu çalışma sonuçlarında da cinsiyete göre baskı ve iletişim düzeylerimde anlamlı bir fark olmadığını belirtmişlerdir. Çalışmamız literatüre uygun sonuçlar vermiştir.

Hakem öz yeterlik ölçeği toplam puan ortalamaları arasında cinsiyet grupları için istatistiksel olarak anlamlı bir fark yoktur. Demirbaş (2014) meslek yüksekokulu öğrencileri üzerinde yapmış olduğu çalışmada cinsiyet değişkeni ile öz-etkililik-yeterlilik ölçeği arasında istatistiksel olarak anlamlı bir ilişki olmadığı sonucuna ulaşıldı. Kaçar ve Beycioğlu (2017) çalışmasında öğretmenlerin öz yeterlik inanç kaynakları cinsiyetlerine göre anlamlı farklılık göstermemiştir. Bu durum çalışmamızla paralellik göstermektedir. $\mathrm{Bu}$ durum kadınların sosyal yaşamda daha aktif rol almaya başlamasıyla birlikte genel olarak yaşanan kadın erkek eşitsizliğinin yavaş yavaş ortadan kalkması olarak yorumlanabilir. 
Bu araştırmada sporda görev ve ego yönelimi ölçeği görev yönelimi ve ego yönelimi alt boyut toplam puan ortalamaları arasında cinsiyet grupları için anlamlı bir fark yoktur. Bu alanda yapılan çalışmalarda araștırmamızdaki bulguları destekler niteliktedir. Bu çalışmalardan biri Çavdarlı (2013) liseli sporcuların katılımıyla yapılmış ve cinsiyetler arasında anlamlı bir farklılık bulamamışlardır. Bir diğer destekleyen çalışmalardan, 112 üniversite öğrencinin katıldığı Budak (2017) ve Kim ve Gill (1997) görev ve ego yönelimlerinin cinsiyetler için bir farklılığın olmadığını tespit ettikleri çalışmaya ise 344 sporcu katılmıştır. Tüm bu çalışmaların dışında Duda (1989) araştırmasında hedef yönelimleri açısından cinsiyetler arasında farklılık bulunmuştur. Bireysel ve takım sporcular üzerine yapılan bu çalışma sonucunda erkek sporcuların kadın sporculara göre daha çok ego ile ilişkili hedef yönelimli olduğu kadın sporcuların ise daha çok görev ile ilişkili hedef yönelimli olduğu sonucuna ulaşılmıştır. Bu durum genel olarak toplumumuzda üst düzey yöneticilerin erkek olması daha başarılı olma isteği ve erkeklerin daha çok söz sahibi olma istekleriyle örtüşmektedir. Kadınlar da ise daha sürece odaklanma ve başarıyı sadece sonuç odaklı algılamadığı şeklinde yorumlanabilir.

Bunların dışında Hakem öz yeterlik ölçeği oyun bilgisi alt boyutu toplam puan ortalamaları arasında cinsiyet grupları için istatistiksel olarak anlamlı bir fark yoktur.

Çalışmamızda meslek gruplarının karar verme alt boyutu toplam puan ortalamaları arasında istatistiksel olarak anlamlı bir fark yoktur. Çalışmamızdan farklı olarak Uzunoğlu (2008) Meslekleri açısından hakemlerin dikkatli karar verme puan ortalamalarında anlamlı bir farklılık olduğu görülmüştür.

Aynı zamanda meslek gruplarının fiziksel yeterlik, oyun bilgisi baskı, iletişim, hakem öz yeterlik ölçeği genel toplam puanı, görev yönelimi ve ego yönelimi alt boyutu toplam puan ortalamaları arasında istatistiksel olarak anlamlı bir fark yoktur. Genel anlamda bireylerin mesleklerinin getirmiş oldukları özelliklerini hakemlik üzerinde bir etkisinin olmadığını düşünebiliriz.

Yaş gruplarının oyun bilgisi, baskı, iletişim ve hakem öz yeterlik ölçeği genel toplam puanı, görev yönelimi ve ego yönelimi alt boyutu toplam puan ortalamaları arasında istatistiksel olarak anlamlı bir fark yoktur.

Yaş gruplarının Fiziksel Yeterlik alt boyutu toplam puan ortalamaları arasında istatistiksel olarak anlamlı bir fark yoktur. Araştırma sonuçlarımıza uygun olarak Karaçam ve Pulur (2017) futbol, basketbol ve hentbol hakemleri üzerine yapmış oldukları çalışmada fiziksel uygunluk ve yaşları arasında anlamlı bir fark bulunamamıştır.

Yaş gruplarının karar verme alt boyutu toplam puan ortalamaları arasında istatistiksel olarak anlamlı bir fark vardır ve farkı belirlemek için yapılan çoklu karşılaştırma testi sonucuna göre 18-25 yaş grubu karar verme alt boyutu toplam puan ortalaması 34-41 yaş grubu ile 50 ve üzeri yaş grubu karar verme alt boyutu toplam puanından daha düşükken, 26-33 yaş grubu karar verme alt boyutu toplam puan ortalaması 34-41 yaş grubu ile 50 ve üzeri yaş grubu karar verme alt boyutu toplam puan ortalamasından daha düşüktür. Bu 
sonuçlar göz önünde bulundurulduğunda yaşla birlikte tecrübe sahibi olmaya başlayan hakemler daha rahat karar vermeye ilerleyen yıllarda karar verme sorunu yaşamamaya başlarlar.

Deneyim gruplarının karar verme alt boyutu toplam puan ortalamaları arasında istatistiksel olarak anlamlı bir fark bulunmuştur. Çoklu karşılaştırma testi sonucuna göre 1-5 yıl deneyim grubu ile 6-10 yıl deneyim grubu karar verme alt boyutu toplam puan ortalaması, 11-15 yll, 16-20 yll, 21-25 yıl ve 26 yll ve üzeri deneyim grubu karar verme alt boyutu toplam puan ortalamasında daha düşüktür. 26 yıl ve üzeri deneyim grubu karar verme alt boyutu toplam puan ortalaması sırasıyla 1-5 yll, 6-10 yıl, 16-20 yıl, 11-15 yll ve 21-25 yıl deneyim grubundan daha yüksektir. Bu sonuçlara göre deneyimle birlikte karar verme durumu daha rahat olmaktadır ancak bu çalışmada deneyim grupları yıllara göre arttıkça karar verme durumu iyileşirken, 11-15 yıl ile 16-20 yıl arasında beklenenin dışında bir durum gelişmiştir. Diğer gruplar sırasıyla ilerlerken 11-15 yıl deneyim grubu 16-20 yıl deneyim grubuna göre daha yüksek karar verme alt boyutu puan ortalamasına sahiptir.

Deneyim gruplarının fiziksel yeterlik, oyun bilgisi, baskl, iletişim ve hakem öz yeterlik ölçeği genel toplam puanı, görev yönelimi ve ego yönelimi alt boyutu toplam puan ortalamaları arasında istatistiksel olarak anlamlı bir fark yoktur.

Klasman gruplarının karar verme alt boyutu toplam puan ortalamaları arasında istatistiksel olarak anlamlı bir fark vardır. Yapılan çoklu karşılaştırma testi sonucuna göre uluslararası klasman grubunun karar verme alt boyutu toplam puan ortalaması ulusal, aday ve il klasman grubu karar verme alt boyutu toplam puan ortalamasından daha düşüktür. Bunun nedeni hakemlerin klasmanlarının aday, il, ulusal ve uluslararası olarak ilerlediğini göz önünde bulundurursak, ilerleyebilecekleri son mevki olan uluslararası klasmana yükseldiklerinde ellerindeki imkanlara göre daha uygun karar vermeleri, klasmanlarda ilerlemek için daha fazla müsabakaya çıkmaları, bununla birlikte çok daha fazla pozisyonla karşılaşmaları ve tüm bunların getirmiş olduğu deneyim ve bilgi birikimine bağlı olabilir.

Klasman gruplarının Ego Yönelimi alt boyutu toplam puan ortalamaları arasında istatistiksel olarak anlamlı bir fark vardır. Çoklu karşılaştırma testi sonucuna göre uluslararası klasman grubunun ego yönelimi alt boyutu toplam puan ortalaması sırasıyla ulusal, aday ve il klasman grubu ego yönelimi alt boyutu toplam puan ortalamasından daha düşüktür. Ego yönelimi alt boyut toplam puanları uluslararası, ulusal, aday ve il olarak artmaktadır. Burada il hakemlerin aday, ulusal ve uluslararası klasmanda ki hakemlere göre daha ego yönelimli oldukları sonucuna varılabilir. Aday hakemlikten sonra il hakemliğine belirli koşulları yerine getirdikten sonra terfi edebilirken il hakemliğinden sonra ulusal hakem olabilmek için hem belirli koşullar yerine getirilmeli hem de İl Hakem Kurulu tarafından sezon sonunda Ulusal hakemliğe terfi için önerilmesi gerekmektedir. Bir voleybol hakemi iki sezon aday hakemlik yaptıktan sonra il hakemliğine terfi edemezse hakemliği düşürülmektedir. Ancak aday hakemliğini başarıyla tamamlayan ve il hakemliğine terfi eden biri hakemlik kariyerini il hakemi olarak tamamlayabilir. Bu durumda ulusal hakemliğe terfi etmek isteyen il klasman 
grubundaki hakemlerin ulusal hakemliğe terfi edebilme düşüncesi nedeniyle diğer klasman gruplarına göre daha sonuç odaklı olabilirler.

Klasman gruplarının fiziksel yeterlik, oyun bilgisi, baskı, iletişim ve hakem öz yeterlik ölçeği genel toplam puanı ve görev yönelimi alt boyutu toplam puan ortalamaları arasında istatistiksel olarak anlamlı bir fark bulunamamıștır.

Şehir gruplarının fiziksel yeterlik, oyun bilgisi, karar verme, baskı, iletişim, hakem öz yeterlik ölçeği genel toplam puan ortalamaları ve görev yönelimi alt boyutu toplam puan ortalamaları arasında istatistiksel olarak anlamlı bir fark yoktur. Şehir gruplarının ego yönelimi alt boyutu toplam puan ortalamaları arasında istatistiksel olarak anlamlı bir fark bulunmuştur. Sadece İzmir ve İstanbul arasında anlamlı bir fark bulunmazken diğer tüm iller arasında anlamlı bir fark bulunmuştur. İzmir ve İstanbul ili hakemlerinin ego yönelimi alt boyutu toplam puan ortalamaları Ankara, Isparta, Aydın, Denizli ve Kayseri ili hakemlerine göre ego yönelimi alt boyutu toplam puan ortalamasından daha düşüktür. Kayseri ili hakemlerinin ego yönelimi alt boyutu toplam puan ortalamaları sırasıyla İzmir, İstanbul, Ankara, Isparta, Aydın, Denizli ili hakemlerine göre ego yönelimi alt boyutu toplam puan ortalamasından daha yüksektir. Bu çalışma için katılan yedi ilin arasında Kayseri'de faal olan hakemlerimizin ego yönelimli puan ortalamalarının daha yüksek olduğunu göstermektedir. Ego yönelimli bireylerin negatif duygu durumuna daha çok; pozitif duygu durumuna ise daha az meyilli olduğu düşünülmektedir (Nicholls, 1989). Bunun sebeplerinden birini Roberts (1992) kazanmak ve kaybetmek olgularının değişken ve kontrolü olmayan durumlar olduğunu ve sonuç olarak kazanma odaklı sporcuların olumsuz duygulara daha yatkın olmasının muhtemel olduğu şeklinde açıklamıştır. Buna karşın görev yönelimli sporcular performans için içsel standartlar geliştirmişlerdir ve bu daha kontrol edilebilir bir durum olduğu için pozitif duygulanım görev yönelimli sporcular arasında daha olasıdır (Roberts, 1992). Duda ve arkadaşları ile Whitehead ve arkadaşları tarafından farklı zamanlarda yapılan araştırmalarda, algılanan düşük yeteneğe sahip bireylerin ego yönelimli durumlarda görev yönelimli durumlara göre daha düşük performans sergiledikleri sonucuna ulaşmışlardır (aktaran. Kelecek, 2013:23-24). Daha kalabalık hakem gruplarına sahip olan İzmir, İstanbul ve Ankara şehirlerinde ego yönelimi daha az çıkarken sonrasında sırasıyla Isparta, Aydın, Denizli ve Kayseri illerinde ego yönelimi alt boyutu ortalama puanları daha yüksek çıkmıştır. Bu İllerde üst liglerde olan takım sayısı da düşünüldüğünde başarının üst liglerde görev almanın kendini başarılı olarak görme şeklinde yorumlanması da mümkündür.

Başarı hedefi yönelimi ve algılanan fiziksel yeterliliğin kendine güven üzerinde etkisini araştıran çok az çalışma bulunmaktadır. Treasure ve Biddle (1997) görev yöneliminin kendine güveni, algılanan yeterliliği ve fiziksel öz-saygıyı doğrudan ve dolaylı olarak öngördüğ̈nü bulmuşlardır. Kavussanu ve Harnisch (2000) yaptıkları bir çalışmada görev yönelimi yüksek olan sporcuların görev yönelimi düşük olanlara göre daha fazla kendine güvenli olduğunu tespit etmişlerdir. Bu alanda yapılan sınırlı çalışmalar görev yöneliminin kendine güveni etkileyeceği yönündedir. Genel olarak görev yönelimi kendine güven üzerinde etkilidir, çünkü kendine 
güven yeterlilik ile ilişkilidir. Ĕger bir birey kendini faaliyet gösterdiği spor dalında yeterli görüyorsa, o bireyin kendine güven duygusu da yüksek düzeyde olacaktır. 


\section{KAYNAKÇA}

Arslanoğlu, E., Tekin, M. Arslanoğlu, C. ve Özmutlu, İ. (2010). Voleybol hakemlerinin çeşitli değişkenlere göre kaygı ve temel psikolojik ihtiyaç düzeylerinin incelenmesi. (Ankara ili Örneği) Uluslararası İnsan Bilimleri Dergisi, 7(2), 985-995.

Boyd, M.P. (1990). The effects of participation orientation and success-failure on post-competitive affect in young athletes [Yayımlanmamış doktora tezi). University of Southern California.

Budak, H.A. (2017). Farklı Güdüsel İklimlerde Performansın Ön Görücüsü Olarak Akış ve Duygusal Zekâa [Yayımlanmamış Yüksek Lisans Tezi]. Manisa Celal Bayar Üniversitesi.

Buldur, S. ve Doğan, A. (2017). Performansa dayalı tekniklerle yürütülen biçimlendirmeye yönelik değerlendirme sürecinin öğrencilerin hedef yönelimlerine etkisi. Hacettepe Üniversitesi Eğitim Fakültesi Dergisi, 32(1), 143-167.

Büyüköztürk, Ş., Kılıç Çakmak, E., Akgün, Ö.E., Karadeniz, Ş. ve Demirel, F. (2014). Bilimsel araştırma yöntemleri (17. Baskı). Ankara: Pegem Yayınları

Bray, S., Balaguer, I., ve Duda, J.L. (2004). The relationship of task self-efficacy and role efficacy beliefs to role performance in Spanish youth soccer. Journal of Sport Sciences, 22 (5), 429-437.

Çavdarlı, Ş. (2013). Liseli sporcularda görev ve ego yönelimleri ile sporda stresle başa çıkma stratejileri arasındaki ilişki[Yayımlanmamış Yüksek Lisans Tezi]. Mersin Üniversitesi.

Demirbaş, Ö. (2014). Meslek yüksekokulu öğrencilerinin öz-yeterlilik düzeyleri ile problem çözme düzeyleri arasındaki ilişkinin incelenmesi [Yayımlanmamış Yüksek Lisans Tezi]. Haliç Üniversitesi.

Duda, J. L. (1989). Goal perspectives, participation and persistence in sport. International Journal of Psychology, $20,42-56$.

Duda, J. L. (1992). “Motivation in Sport Setting: A Goal Perspective Approach, In Roberts”, Motivation in Sport and Exercise, Champaign, Illinois:Human Kinetics, pp. 57- 91.

Duda, J.L. ve Chi, L. (1989). The effect of task and ego involving conditions on perceived competence and causal attributions in basketball. Makale Uygulamalı Spor Psikoloji Birliği, University of Washington, Seattle.

Duda, J.L., ve Nicholls, J. (1992). Dimensions of leadership behavior in sport: Development of a leadership scale. Journal of Sport Psychology, 2, 34-45.

Duda, J. L., \& White, S. A., (1992). Goal orientations and beliefs about the cause of sport success among elite skiers. The Sport Psychologist, 6, 334-343.

Duda, J.L., Chi, L., Newton, M.L., Walling, M.D., ve Catley, D. (1995). Task and ego orientation and intrinsic motivation in sport. International Journal of Sport Psychology, 26,40-63. 
Voleybol Hakemlerinin Ego ve Görev Yönelimleri Bakımından Öz Yeterliklerinin İncelenmesi

Doğan, K. ve Elçi, S. (2017). Sporda Ego ve Görev Yönelimi Ölçeği (SEGYÖ)'nin Hakemler için Adaptasyon Çalışması. Beden Eğitimi ve Spor Bilimleri Dergisi, 19(2), 68-77.

Jacobsen, D.A., Eggen, P. ve Kauchak, D. (2002). Methods for teaching, Promoting student learning, Sixth Edition, Merrill Prentice Hall, New Jersey, USA

Kaçar, T. ve Beycioğlu K.(2017). İlköğretim Öğretmenlerinin Öz Yeterlik İnançlarının Çeşitli Değişkenler Açısından İncelenmesi, İlköğretim Online, 16(4), 1753-1767.

Karaçam, A. ve Pulur, A. (2017). Hakem Öz Yeterlik Ölçeği'nin (HÖYÖ) Türkçeye uyarlama çalışması. Niğde Üniversitesi Beden Eğitimi ve Spor Bilimleri Dergisi,11(1), 118-128.

Karaçam, A. ve Pulur A. (2017). Examining the Relationship between Referee Self-efficacy and General Selfefficacy Levels of Basketball Referees in Terms of Certain Variables. Journal of Education and Training Studies, vol.5, 37-45.

Karaçam, A. ve Pulur A. (2017). Examining the Relationship between Referee Self-efficacy and General Selfefficacy Levels of Football, Basketball and Handball Referees. Universal Journal of Educational Research , 5, 1571-1579.

Karataş, Ö., Biçer, Y.S., Yıldırım, E. ve Çevrim, H. (2013). Hentbol, basketbol, Voleybol Klasman hakemlerinin iş doyumu düzeylerin incelenmesi. Sport Sciences , 8 (2) , 35-45.

Kavussanu, M. ve Harnisch D.L. (2000). Self-esteem in children: Do goal orientations matter? British Journal of Educational Psychology, 70(2), 229-242.

Kaygusuz Ș., Körmükçü, Y. ve Adalı, H. (2016) Beden eğitimi ve spor yüksekokulu öğrencilerinin yaşam doyum durumları ile sporda görev ve ego yönelimi durumlarının bazı değişkenler tarafından incelenmesi. International Journal of Science Culture and Sport, s.854

Kelecek, S. (2013). Sporcuların Tutkunluk Düzeylerinin; Optimal Performans Duygu Durumu, Güdüsel Yönelim ve Hedef Yönelimini Belirlemedeki Rolü [Yayımlanmamış Yüksek Lisans Tezi]. Başkent Üniversitesi.

Kim, B. J. \& Gill, D.L. (1997). A Cross-Cultural Extension of Goal Perspective Theory to Korean Youth Sport. Journal of Sport and Exercise Psychology, 19, 142-155.

Myers, N. D., Feltz, D. L., Guillén, F., ve Dithurbide, L. (2012). Development of, and initial validity evidence for, the Referee Self-Efficacy Scale: A multistudy report. Journal of sport and Exercise Psychology, 34(6), 737 765.

Nicholls J.G. (1989). The competitive ethos and democratic education. Cambridge, MA: Harvard University Press. Ornstein, A.C. \& Lasley, T.J. (2000). Strategies for Effective Teaching, Third Edition, The McGraw-Hill Companies, USA. 
Voleybol Hakemlerinin Ego ve Görev Yönelimleri Bakımından Öz Yeterliklerinin İncelenmesi

Öztürk Kuter, F. (1997). “Üniversite Gençliğinin Futbolda Takım Tutma Durumlarının Karşılaştırılması”, 1. Uluslararası Spor Psikolojisi Sempozyumu, 51, Mersin.

Pepe, H., Filiz, K., Pepe, K. ve Can, S. (1999). Futbol hakemlerinin hakemlik geçmişleri ve sporculuk geçmişlerinin tutarlı karar vermedeki etkisinin incelenmesi. Beden Eğitimi ve Spor Bilimleri Dergisi, 1, 26-33.

Roberts, G.C. (1992) Motivation in sport and exercise: Conceptual constraints and convergence. In: Roberts GC. (Ed.). Motivation in Sport and Exercise. Champaign, IL: Human Kinetics, p. 3-29.

Toros, T. (2000). Sporda görev ve ego yönelimi ölçeğinin Turk sporcuları için uyarlama ön çalışması. Uluslararası Spor Bilimleri Kongresi. 11-13 Mayıs, İstanbul.

Toros, T. (2001). Elit ve Elit olmayan erkek basketbolcularda hedef yönelimi, güdüsel iklim ve hedeflerin özgünlük güçlük derecesi özelliklerinin yaşam doyumuna etkisi [Yayımlanmamış Yüksek Lisans Tezi]. Mersin Üniversitesi.

Toros, T. (2002). Elit ve elit olmayan erkek basketbolcularda hedef yönelimi, güdüsel (motivasyonel) iklim ve yaşam doyumu. H.Ü. Spor Bilimleri Dergisi. 13(3), pp. 24-36.

Toy A. B. (2015) Serbest ve Grekoromen Stil Güreşçilerin Hedef Yönelimi ve Yaşam Doyumu İlişkisi [Yayımlanmamış Yüksek Lisans Tezi]. Hitit Üniversitesi.

Treasure, D.C. ve Biddle, S. (1997). North American Society of the Psychology of Sport and Physical Activity: Antecedents of physical self-worth and global self-esteem: Influence of achievement goal orientations and perceived ability, Denver, Colorado.

Roberts, G.C. (1992). Motivation in sport and exercise: Conceptual constraints and convergence. In: Roberts GC. (Ed.). Motivation in Sport and Exercise. Champaign, IL: Human Kinetics, p. 3-29.

Uzunoğlu, Ö.U. (2008). Türk Futbol Hakemlerinin Karar Verme Stillerinin Klasmanlarına ve Bazı Değişsenlere Göre İncelenmesi [Yayımlanmamış Yüksek Lisans Tezi]. Selçuk Üniversitesi.

White, S. A., \& Duda, J. L. (1994). The relationship of gender, level of sport involvement, and participation motivation to task and ego orientation. International Journal of Sport Psychology, 25(1), 4-18.

Walling, M.D. \& Duda, J.L. (1995). Goals and their associations with beliefs about success in the perceptions of the purpose of physical education. J Teaching in Physical Education, 14, 140-156.

Weinberg, R. S., \& Gould, D. (1995). Foundations of sport and exercise psychology. Champaign, IL: Human Kinetics. 


\section{EXTENDED ABSTRACT}

\section{Introduction.}

The aim of this research is to investigate whether the relationship between ego and task orientation and self-efficacy of volleyball referees has changed according to their demographic characteristics.

\section{Method.}

The study group consisted of 279 volleyball referees who were active in İzmir, Kayseri, Denizli, Aydın, Ankara, İstanbul and Isparta during 2017-2018 season. The Task and Ego Orientation in Sport Questionnaire (TEOSQ) and the referee self-efficacy scale (REFS) and the socio-demographic data form were used as data collection tools. One-way analysis of variance (ANOVA) and t-test (t-test) for unconnected groups were included in the evaluation of the data. In the analysis of variance, the Tukey-B multiple comparison test was applied for differences between the groups.

\section{Results.}

It has been found that physical competence, gaming knowledge, decision making, printing, communication, (REFS) total score and task orientation subscales each have a significant relationship with each other, and with ego orientation subscale and only task orientation subscale. The sub-dimension of physical competence and decision making sub-dimension according to gender groups, decision making sub-dimension of age $(F(4,261)=3,660, p<0,05)$ and Experience $(F(5,258)=3,295, p<0,05)$ The ego orientation subdimension of city groups $(F(6,267)=3,912, p<0,05)$ and ego orientation subdimension $(F(3,267)=6,190$; $\mathrm{p}<0,05$ ), there was no statistically significant difference between the mean scores of the subscales of the occupational groups.

\section{Discussion \& Conclusion.}

As a result of the research, it has been found that volleyball referees have a meaningful relationship between ego and task orientation and self-efficacy, and there are differences between gender, age, experience, city and classroom variables. The referee self-efficacy scale sub-physical efficacy, game knowledge, decisionmaking, pressure, communication, total score of HÖYÖ, and SEGYÖ task orientation sub-dimensions have a significant relationship with each other. However, ego and task orientation in sports, the ego orientation subdimension was found to have a significant relationship only with the task orientation sub-dimension. It was found that the highest correlation was found between the total HÖYÖ score and the game knowledge subdimension, while the lowest correlation was found between the SEGYÖ task orientation sub-dimension and pressure. It has been concluded that the lowest relationship among the HÖYÖ itself is between the pressure and physical competence sub-dimensions. In our study, there is a statistically significant difference for the total mean scores of the referee self-efficacy scale physical efficacy sub-dimension and decision-making subdimension according to gender groups. Male referees had higher scores for physical competence and decision making sub-dimensions than female referees. The 18-25 age group decision-making sub-dimension mean total 
score is lower than the 34-41 age group and the 50 and over age group decision-making sub-dimension total score. The total score average of the 26-33 age group decision making sub-dimension is lower than the total score average of the 34-41 age group and the 50 and over age group decision-making sub-dimension. The decision-making sub-dimension of the 1-5 years experience group is lower than the total score average of the decision-making sub-dimension of 11-15 years, 16-20 years, 21-25 years and 26 years and more. The decisionmaking sub-dimension of the 6-10 years experience group has a lower total score average of 11-15 years, 16-20 years, 21-25 years, and the decision-making sub-dimension of 26 and above experience group. The total score average of the 26 years and more experience group decision-making sub-dimension is higher than the 1-5 years, 6-10 years, 16-20 years, 11-15 years and 21-25 years experience group, respectively. According to these results, the decision-making situation with experience becomes more comfortable, but in this study, as the experience groups increase over the years, the decision-making situation improves, while an unexpected situation has developed between 11-15 years and 16-20 years. While the other groups progress respectively, the 16-20 years experience group has a higher decision-making sub-dimension score average than the 11-15 years experience group. In general, as the years of experience of volleyball referees increase, they can make more confident decisions. The total score average of the decision-making sub-dimension of the international classification group is higher than the average score of the candidate, province and national classification group. The total score average of the ego orientation sub-dimension of the international classification group is lower than the total score average of the national, candidate and provincial classification group ego orientation sub-dimension. According to the referees of Ankara, Isparta and Kayseri provinces, the sub-dimension of ego orientation of Izmir province referees is lower than the total score average. According to the referees of Ankara, Isparta, Aydın, Denizli, and Kayseri provinces of Istanbul, the ego orientation sub-dimension is lower than the total score average. According to the referees of İzmir, İstanbul, Ankara, Isparta, Aydın, Denizli provincial referees of Kayseri province, the ego orientation sub-dimension is higher than the total score average. For the purpose of the study, the factors affecting self-confidence were investigated, and as a result of examining the relationship between ego and task orientation and self-efficacy, it was concluded that only the task orientation sub-dimension was related to the referee self-efficacy sub-dimensions. However, a significant relationship was found between independent variables and ego orientation sub-dimension. According to these results, a qualitative study can be done to investigate this in more detail in the next studies. The reasons for the differences between city groups can be investigated and studies can be carried out accordingly to contribute to the better functioning of the referees. In general, it can be made more efficient by looking at the works of the Provincial Referee Boards in the provinces during the year. For example, trainings can be done according to needs. The literature can be enriched more when the relationship between them is examined by increasing the number of samples and the number of influencing factors. 